\title{
A Microwave-Enhanced Synthesis and Biological Evaluation of $N$-Aryl-5,6,7,8-tetrahydrobenzo[4,5]thieno[2,3-d]pyrimidin-4-amines
}

\author{
Qing Han, ${ }^{\oplus a, b}$ Zijian Yin, ${ }^{c}$ Jingjiao Sui, ${ }^{d}$ Qingming Wang $^{a}$ and Yaquan Sun*,a,b,e \\ ${ }^{a}$ School of Pharmacy, Yancheng Teachers University, 224051 Yancheng, PR China \\ ${ }^{b}$ Institute of Chemical Technology, Nanjing Tech University, 210000 Nanjing, PR China \\ 'School of Pharmaceutical Engineering \& Life Science, Changzhou University, \\ 213164 Changzhou, PR China \\ ${ }^{d}$ Institute of Chemical Technology, Shanghai University of Engineering Science, \\ 201620 Shanghai, PR China \\ eJiangsu Marine Industry Research Institute, 224051 Yancheng, PR China
}

\begin{abstract}
A series of $N$-aryl-5,6,7,8-tetra-hydrobenzo[4,5]thieno[2,3- $d$ ]pyrimidin-4-amines were synthesized in moderate to good yield by using a microwave-enhanced conditions. The selected compounds were evaluated for their cytotoxic effects $\left(\mathrm{IC}_{50}\right.$ values) on human pulmonary carcinoma (A549), murine BALB/c spontaneous colon adenocarcinoma (CT26) and human hepatocellular liver carcinoma (HepG2) cell lines in vitro. Amongst these compounds, one compound was found to have the better cytotoxic activity with reference to the standard Erlotinib hydrochloride (Tarceva ${ }^{\mathrm{TM}}$ ) against A549 $\left(\mathrm{IC}_{50}=16.06 \pm 0.09 \mu \mathrm{M}\right)$ and HepG2 $\left(\mathrm{IC}_{50}=15.01 \pm 0.31 \mu \mathrm{M}\right)$ cell lines. Especially, two compounds showed best cytotoxic effects against CT26 ( $\left.\mathrm{IC}_{50}=11.38 \pm 0.44 \mu \mathrm{M}\right)$ and HepG2 $\left(\mathrm{IC}_{50}=8.51 \pm 0.52 \mu \mathrm{M}\right)$ cell lines, respectively. The preliminary structure-activity relationships were disclosed and the thieno[2,3- $d]$ pyrimidine skeleton could be exploited to potential antitumor agents in the future.
\end{abstract}

Keywords: thieno[2,3- $d]$ pyrimidine, microwave-enhanced, Gewald reaction, Dimroth rearrangement, biological evaluation

\section{Introduction}

In investigation, we found the presence of several marketed anticancer drugs such as gefitinib I (Iressa $\left.{ }^{\mathrm{TM}}\right),{ }^{1}$ vandetanib II $\left(\right.$ Caprelsa $\left.^{\mathrm{TM}}\right),{ }^{2}$ lapatinib III $\left(\right.$ Tykerb $\left.^{\mathrm{TM}}\right),{ }^{3}$ erlotinib IV (Tarceva $\left.{ }^{\mathrm{TM}}\right),{ }^{4}$ tandutinib V (MLN518)

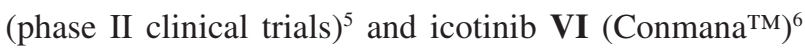
(Figure 1), which have a quinazoline nucleus, the thieno[2,3- $d]$ pyrimidine core can be considered a bioisostere of this quinazoline core. ${ }^{7}$

In literatures, ${ }^{8-10}$ thieno[2,3- $d$ ]pyrimidin-4-amine derivatives exhibit a broad range of biological and pharmacological activities associated with their heterocyclic scaffold and have been widely used in the medical field. Thieno[2,3- $d$ ]pyrimidin-4-amine displays a wide range of biological activity including anti-tumor, ${ }^{11}$ anti-bacterial, ${ }^{12}$

*e-mail: sunyaquan@ hotmail.com anti-leukemia, ${ }^{13,14}$ antiviral, ${ }^{15}$ anti-inflammatory ${ }^{16}$ and anti-diabetic properties. ${ }^{17}$ As such, many antitumor agents based on thieno[2,3- $d]$ pyrimidine have been reported by researchers. Yang et al. ${ }^{18}$ synthesized two series of thieno[2,3-d]pyrimidine derivatives and evaluated for cytotoxic activity in human pulmonary carcinoma cell line (A549). Of these compounds, one showed the most cytotoxic effect on A549 cells with half maximal inhibitory concentration $\left(\mathrm{IC}_{50}\right.$ ) value of $4.87 \mu \mathrm{M}$ (Figure 2, compound VII). Gryshchenko et al..$^{19}$ reported the synthesis of $N$-phenylthieno[2,3- $d$ ] pyrimidin-4-amines, and evaluated for their ability to inhibit enzymatic activity of the fibroblast growth factor receptor 1 (FGFR1). In these compounds, compounds VIII and IX exhibited most effects, with $\mathrm{IC}_{50}$ values of 0.18 and $0.16 \mu \mathrm{M}$, respectively. Abbas et al. ${ }^{20}$ synthesized two series of new tetrahydrobenzo[4,5] thieno[2,3-d]pyrimidines (2,3-disubstituted derivatives and 2,4-disubstituted ones) and evaluated for their cytotoxic 


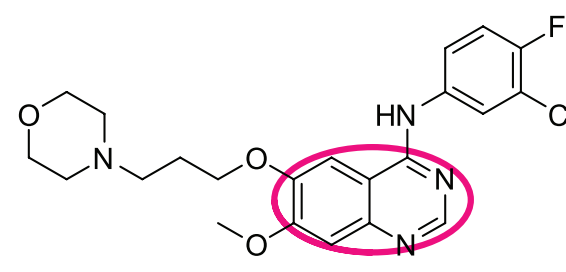

Gefitinib (Iressa ${ }^{\mathrm{TM}}$ )-AstraZeneca

I

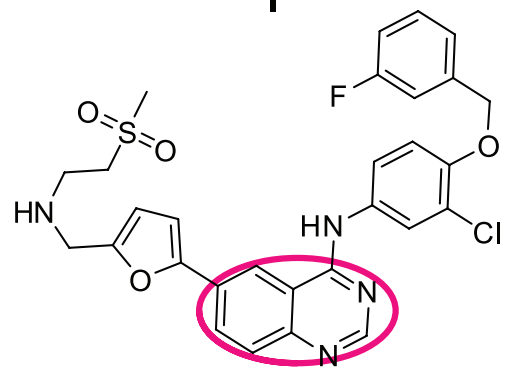

Lapatinib $\left(\right.$ Tykerb $\left.^{\mathrm{TM}}\right)$-GSK

III<smiles>COc1ccc(Nc2ccc(Br)cc2F)c2c1CCN(c1ncccc1F)C2</smiles>

Vandetanib (Caprelsa $\left.{ }^{\mathrm{TM}}\right)$-AstraZeneca

II

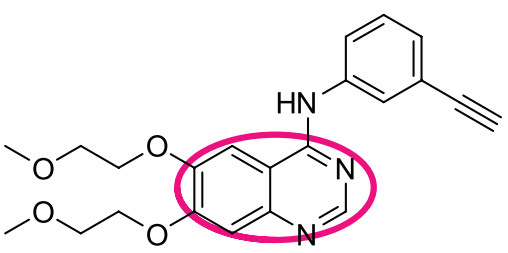

Erlotinib (Tarceva $\left.{ }^{\mathrm{TM}}\right)$-Roche

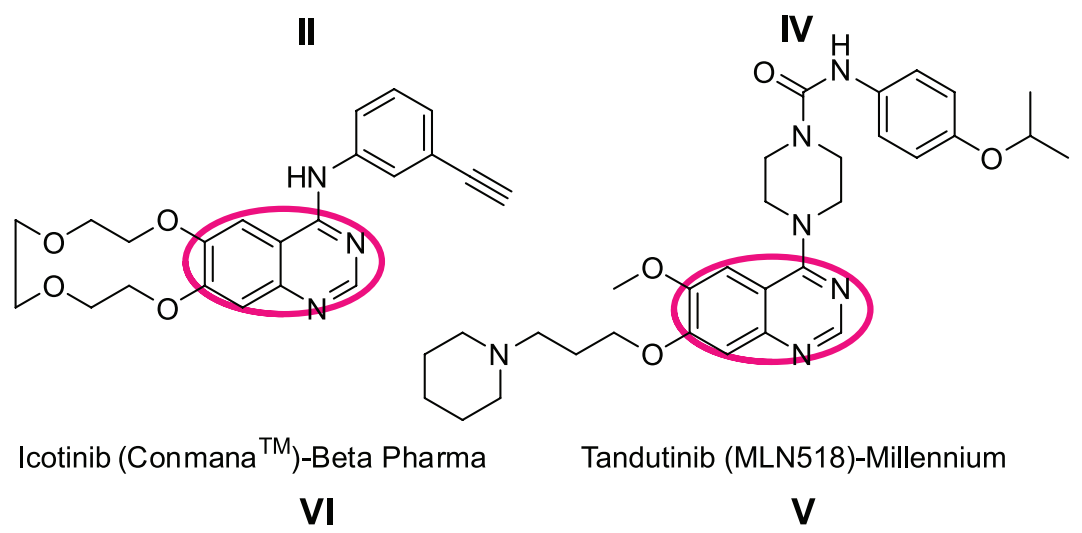

Figure 1. Representative examples of potent anticancer quinazoline drugs.

activity. According to the results, compound $\mathbf{X}$ was found to have the highest cytotoxic activity against breast MCF-7 with $\mathrm{IC}_{50}=15.01 \mu \mathrm{M}$, and $\mathbf{X I}$ showed to be the most active one to inhibit human hepatocellular liver carcinoma cell line (HepG2) with $\mathrm{IC}_{50}=1.29 \mu \mathrm{M}$. Besides, compound XII $^{21}$ showed the best FLT3 (FMS-like receptor tyrosine kinase 3) cytotoxic activity, with $\mathrm{IC}_{50}$ value of $0.065 \mu \mathrm{M}$.

Herein, we take into consideration that the compounds of thieno[2,3- $d]$ pyrimidine skeleton express an important biological cytotoxic activity, and intend to synthesize a series of thieno[2,3- $d$ ]pyrimidine derivatives.

In this study, we are interested in the widely reported cytotoxic activity of thieno[2,3- $d$ ] pyrimidine derivatives via different synthetic methods. Four strategies used for the synthesis of various thieno[2,3- $d$ ] pyrimidine scaffolds have been reported in literatures (Figure 3). ${ }^{11,14,22-29}$ The first method involves the synthesis of thieno[2,3-d] pyrimidin-4(3H)-one (XVII) from compounds XIV, $\mathbf{X V}$ and $\mathbf{X V I}$, then, compound $\mathbf{X V I I}$ is converted to 4-chlorothieno[2,3- $d$ ]pyrimidine (XIX), and the target compound $\mathbf{X X}$ is obtained from XIX. The second route is that the compound XIII is directly converted to compound $\mathbf{X V I I}$, and the final compound $\mathbf{X X}$ can be obtained from XVII. The third protocol is the direct synthesis of 4-chlorothieno[2,3-d]pyrimidine (XIX) from compound $\mathbf{X V}$. The fourth method is the synthesis<smiles>Cc1cc2c(=O)[nH]c(CSC(=S)NCc3ccc(C#N)cc3)nc2s1</smiles>

VII<smiles>Oc1cccc(Nc2ncnc3scc(-c4ccccc4)c23)c1</smiles>

VIII<smiles>Oc1cccc(Nc2ncnc3sc(-c4ccccc4)cc23)c1</smiles>

IX<smiles>[X]c1ccccc1/C=C/c1nc2sc3c(c2c(=O)n1-c1ccc2c(C)c4ccc(N)cc4nc2c1)CCCC3</smiles>

$\mathbf{X}$<smiles>NS(=O)(=O)c1ccc(-n2c(/C=C/c3ccccc3)nc3sc4c(c3c2=O)CCCC4)cc1</smiles>

$\mathbf{X I}$<smiles>CC1=CC(=O)N(Nc2nc(-c3cccs3)nc3scc(C)c23)C1=O</smiles>

Figure 2. Thieno[2,3- $d]$ pyrimidine derivatives in literatures. ${ }^{18-21}$ 


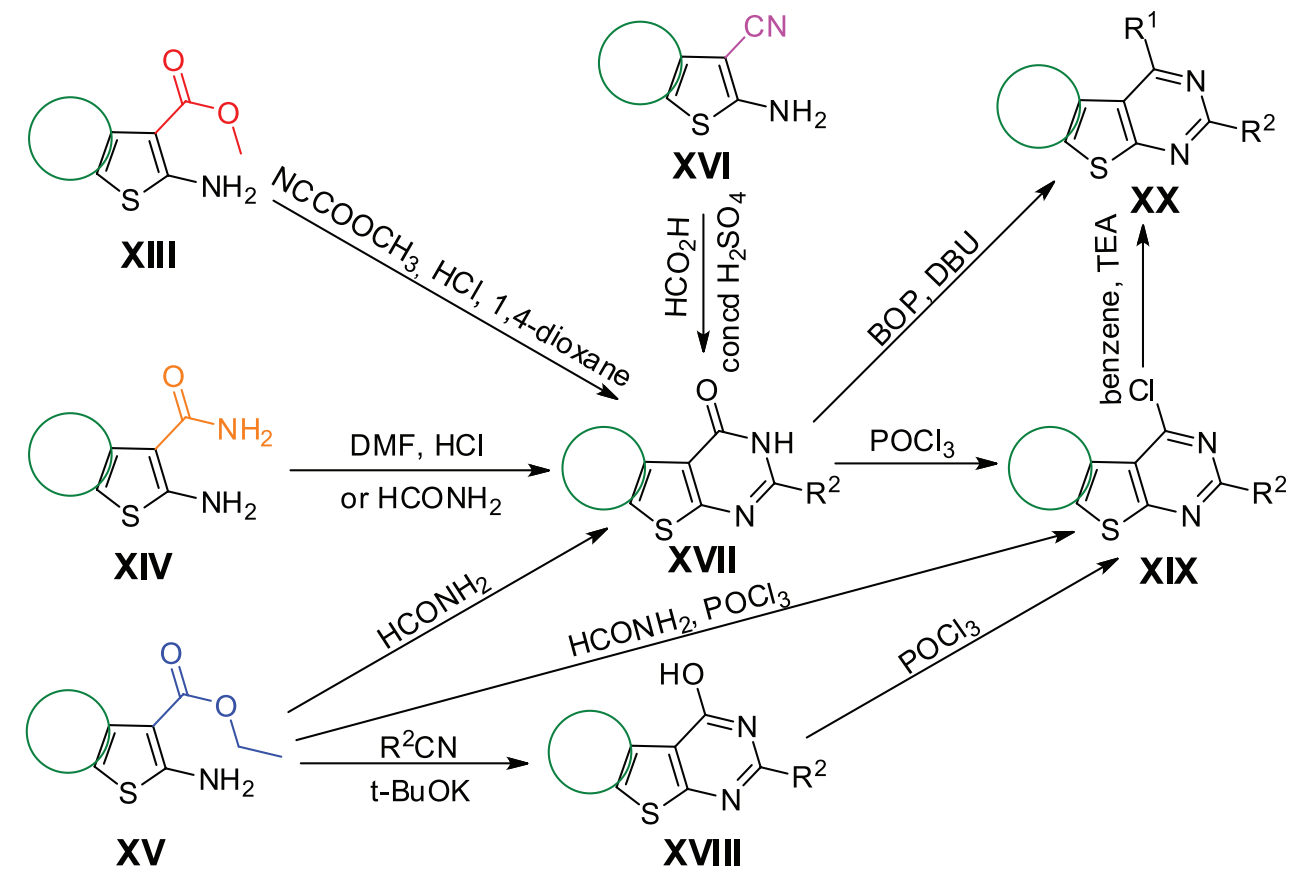

Figure 3. A summary of the synthetic approaches for thieno[2,3- $d$ ]pyrimidines in literatures..$^{11,14,22-29}$

of compound XVIII from XV, subsequently, compound $\mathbf{X V}$ is converted to compound $\mathbf{X I X}$, therefore, the target compound $\mathbf{X X}$ can be synthesized by $\mathbf{X V}$.

Microwave irradiation technology in organic synthesis is a powerful tool for drug synthesis as it can speed up the reactions under mild conditions allowing the rapid preparation of compounds. ${ }^{30}$ As mentioned above, microwave irradiation technology has been successfully applied to the synthesis of $N$-arylthieno[2,3- $d$ ] pyrimidine derivatives. Our recent endeavors involving green chemical techniques have focused on the synthesis of small organic molecular compounds. Then, in earlier work from our lab, we have reported the synthesis of 6-bromopyrido[2,3- $d$ ] pyrimidine derivatives $(\mathbf{X X I}),{ }^{31}$ pyrido[2,3- $d$ ] pyrimidine derivatives (XXII), ${ }^{32}$ cyclopenta[4,5] thieno[2,3-d]pyrimidine derivatives $(\mathbf{X X I I I})^{33}$ by microwave irradiation technology (Figure 4).

Interestingly, a compound of similar structure
(Figure 4, compound XXIV) ${ }^{34}$ was evaluated to inhibit EGFR (epidermal growth factor receptor) kinase activity with the enzyme inhibition $\mathrm{IC}_{50}=2.6 \mu \mathrm{M}$. Herein, thieno[2,3- $d$ ]pyrimidine skeleton of compounds XXIII and XXIV were used as a template, and the structure was modified: (Figure 4a) hexatomic ring was linked to thiophene ring instead of five membered ring (compound XXIII); (Figure 4b) substituted aromatic group was linked to secondary amine and $-\mathrm{CH}_{2}$ group was subtracted (compound XXIV). Subsequently, compounds 3a-x (Scheme 1) were obtained.

In this study, two questions would be solved: (i) a series of $N$-aryl-5,6,7,8-tetra hydrobenzo[4,5]thieno $[2,3-d]$ pyrimidin-4-amines (3a-x) were obtained with the aid of microwave irradiation technology (Figure 5); (ii) the cytotoxic activity of synthesized compounds were evaluated against A549, murine BALB/c spontaneous colon adenocarcinoma cell line (CT26), and HepG2.
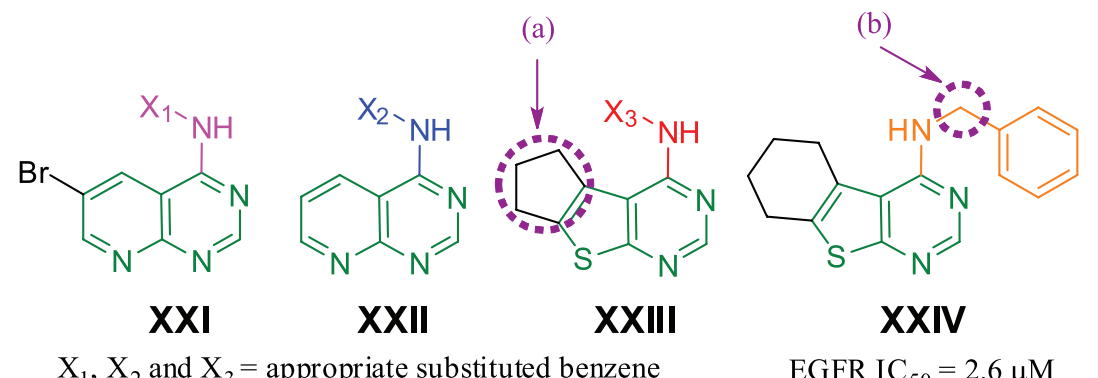

$\mathrm{X}_{1}, \mathrm{X}_{2}$ and $\mathrm{X}_{3}=$ appropriate substituted benzene

$\mathrm{EGFR} \mathrm{IC}_{50}=2.6 \mu \mathrm{M}$

Figure 4. Structures of compounds XXI, XXII, XXIII, XXIV. (a) Hexatomic ring was linked to thiophene ring instead of five membered ring (compound XXIII); (b) substituted aromatic group was linked to secondary amine and $-\mathrm{CH}_{2}$ group was subtracted (compound XXIV). 


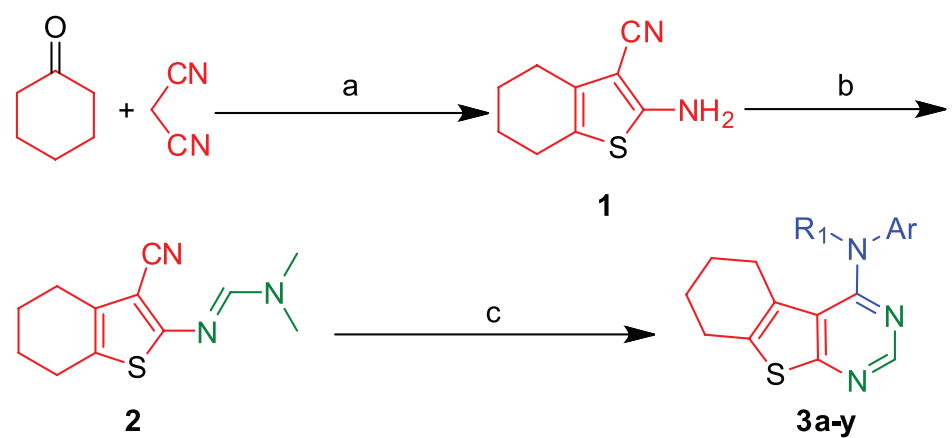
3a: $\mathrm{R}_{1}=\mathrm{H}, \mathrm{Ar}=\mathrm{Ph} \quad 3 \mathrm{~h}: \mathrm{R}_{1}=\mathrm{H}, \mathrm{Ar}=m-\mathrm{FPh}$
3b: $\mathrm{R}_{1}=\mathrm{H}, \mathrm{Ar}=m-\mathrm{MePh} 3 \mathbf{i}: \quad \mathrm{R}_{1}=\mathrm{H}, \mathrm{Ar}=p-\mathrm{FPh}$
3o: $\mathrm{R}_{1}=\mathrm{Me}, \mathrm{Ar}=\mathrm{Ph} ; \quad 3 v: \mathrm{R}_{1}=\mathrm{H}, \mathrm{Ar}=m-\mathrm{CF}_{3} \mathrm{Ph}$;
3c: $\mathrm{R}_{1}=\mathrm{H}, \mathrm{Ar}=p-\mathrm{MePh} 3 \mathrm{j}: \quad \mathrm{R}_{1}=\mathrm{H}, \mathrm{Ar}=m-\mathrm{MeOPh}$
3p: $\mathrm{R}_{1}=\mathrm{H}, \quad \mathrm{Ar}=3,5-\mathrm{DiMePh} ; \mathbf{3} \mathbf{w}: \mathrm{R}_{1}=\mathrm{H}, \mathrm{Ar}=m-t-B u P h$;
3d: $\mathrm{R}_{1}=\mathrm{H}, \mathrm{Ar}=m-\mathrm{CIPh} 3 \mathbf{k}: \mathrm{R}_{1}=\mathrm{H}, \mathrm{Ar}=p-\mathrm{MeOPh}$
3q: $\mathrm{R}_{1}=\mathrm{H}, \quad \mathrm{Ar}=p-t-\mathrm{BuPh}$;
3x: $\mathrm{R}_{1}=\mathrm{H}, \mathrm{Ar}=p-\mathrm{CF}_{3} \mathrm{Ph}$;
3e: $\mathrm{R}_{1}=\mathrm{H}, \mathrm{Ar}=p-\mathrm{ClPh} \quad 3 \mathrm{l}: \quad \mathrm{R}_{1}=\mathrm{H}, \mathrm{Ar}=m-\mathrm{AcPh}$
3r: $\mathrm{R}_{1}=\mathrm{H}, \quad \mathrm{Ar}=3,4-\mathrm{DiCIPh} ; 3 \mathrm{y}^{\mathrm{a}}: \mathrm{R}_{1}=\mathrm{H}, \mathrm{Ar}=p$-AcetylenePh
3f: $\mathrm{R}_{1}=\mathrm{H}, \mathrm{Ar}=m-\mathrm{BrPh} 3 \mathrm{~m}: \mathrm{R}_{1}=\mathrm{H}, \mathrm{Ar}=p-\mathrm{NO}_{2} \mathrm{Ph}$
3s: $R_{1}=H, A r=3,5-D i C I P h$;
3g: $\mathrm{R}_{1}=\mathrm{H}, \mathrm{Ar}=p-\operatorname{BrPh}$ 3n: $\mathrm{R}_{1}=\mathrm{H}, \mathrm{Ar}=m$-AcetylenePh $3 \mathbf{u}: \mathrm{R}_{1}=\mathrm{H}, \quad \operatorname{Ar}=3,5-\mathrm{DiFPh}$;

Scheme 1. Synthetic route of target compounds 3a-y. Reagents and conditions: (a) $\mathrm{S}_{8}, \mathrm{~K}_{2} \mathrm{CO}_{3}, \mathrm{EtOH}$, microwave irradiation (MWI), $85{ }^{\circ} \mathrm{C}, 15 \mathrm{~min}, 95 \%$; (b) DMF-DMA, MWI, $78{ }^{\circ} \mathrm{C}, 5 \mathrm{~min}, 98 \%$; (c) $\mathrm{ArNH}_{2}, \mathrm{AcOH}, \mathrm{MWI}, 90^{\circ} \mathrm{C}, 10 \mathrm{~min}, 28-83 \%$. ${ }^{\mathrm{a}} \mathrm{y}$ : this compound could not be obtained under the reaction conditions.

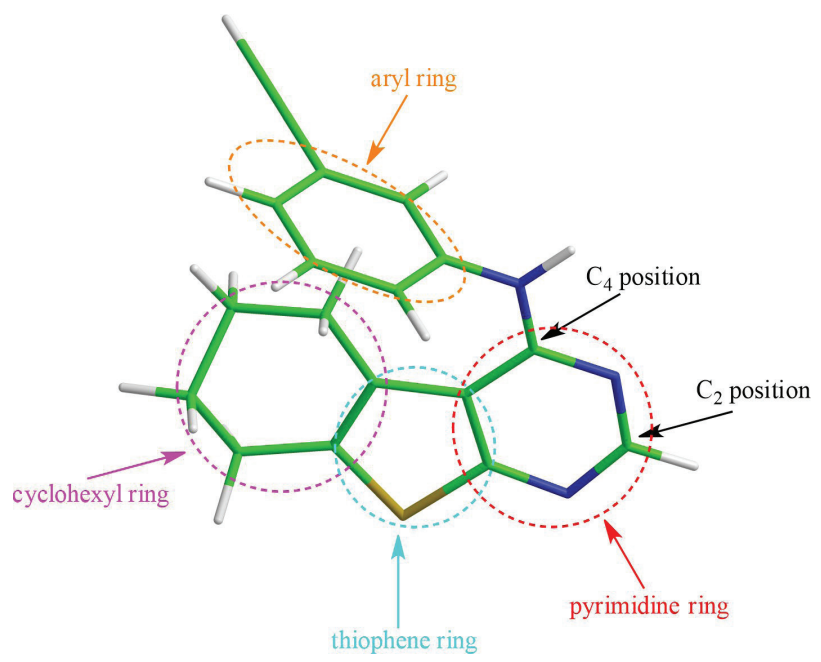

Figure 5. Main structure of synthesized compounds (example: new compound 3n).

\section{Results and Discussion}

\section{Synthesis}

The synthetic strategy used in this study is outlined in Scheme 1. 2-Amino-4,5,6,7-tetrahydrobenzo[b]thiophene3 -carbonitrile was prepared using a modified Gewald procedure via the reaction of cyclohexanone, malononitrile and sulfur in the presence of potassium carbonate $\left(\mathrm{K}_{2} \mathrm{CO}_{3}\right)$, which serves as a heterogeneous solid basic catalyst, in ethanol. To show the merits of the present work, we compared the as-obtained results using $\mathrm{K}_{2} \mathrm{CO}_{3}$ with those previously reported in the literature..$^{35-40}$

It was found that our method can achieve the target product in $95 \%$ yield in 15 min of reaction. Compared to the results in the literature, ${ }^{35-40}$ our method has a shorter reaction time and high yield. So, under the assistance of the microwave irradiation, $\mathrm{K}_{2} \mathrm{CO}_{3}$ can act as a cheap, highly efficient, and green catalyst used to prepare compound $\mathbf{1}$ in high yield over a short reaction time.

As for the synthesis of the intermediate compound 2 ( $N$ '-(3-cyano-4,5,6,7-tetrahydrobenzo[b]-thio phen-2-yl)$N, N$-dimethyl-formimidamide), Loidreau et al. ${ }^{41}$ have reported that 2-amino-5-bromothiophene-3-carbonitrile reacts with $N, N$-dimethylformamide dimethyl acetal (DMF-DMA) to give $N^{\prime}$-(3-cyanothiophen-2-yl)$N, N$-dimethylformimidamide under conventional heating. Meanwhile, Loidreau et al. ${ }^{41}$ described the synthesis of $N^{\prime}$-(2-cyano-benzo[b]thiophen-3-yl)- $N, N$-dimethylformimidamide in high yield upon the reaction of 3-aminobenzo[ $b]$ thiophene-2-carbonitrile and DMF-DMA with the aid of microwave irradiation. Inspired by these methods, we attempted to use 2-amino-4,5,6,7-tetrahydrobenzo [b]thiophene-3-carbonitrile to react with DMF-DMA under the microwave irradiation and obtained compound $\mathbf{2}$ in excellent yields (98\%). This method not only reduces the reaction time (only $5 \mathrm{~min}$ ) with good yield, but also has an easy work-up procedure.

The synthesis of compounds 3a-x (Table 1) involved the acid-catalyzed Dimroth rearrangement between compound 2 and an appropriate aromatic amine under microwave irradiation. It was found that the reaction between $m, p$-substituted aromatic amines and compound $\mathbf{2}$ can easily occur in high yield with a short reaction time. However, the reaction between $o$-substituted aromatic 
amines and compound $\mathbf{2}$ only formed trace amounts of the desired compounds under the same reaction conditions. This new synthetic route involves only three steps making this procedure simple and efficient. Hence, this method is an efficient method for the synthesis of $\mathrm{N}$-arylthieno-

Table 1. Preparation of the compounds 3a-x

\begin{tabular}{|c|c|c|c|c|}
\hline Compound & $\mathrm{R}^{1}$ & $\mathrm{Ar}$ & $\begin{array}{c}\mathrm{mp} / \mathrm{mp} \text { literature / } \\
{ }^{\circ} \mathrm{C}\end{array}$ & Yield ${ }^{\mathrm{a}} / \%$ \\
\hline $\mathbf{3 a}$ & $\mathrm{H}$ & $\mathrm{Ph}$ & $177.7-178.7 / 176-178^{22}$ & 83 \\
\hline $3 \mathbf{b}$ & $\mathrm{H}$ & $m-\mathrm{MePh}$ & 138.1-139.5/- & 69 \\
\hline $3 c$ & $\mathrm{H}$ & $p$-MePh & $151.4-153.1 / 141-143^{23}$ & 82 \\
\hline 3d & $\mathrm{H}$ & $m$-ClPh & $153.4-154.8 / 168^{42}$ & 71 \\
\hline $3 e$ & $\mathrm{H}$ & $p$-ClPh & $142.2-144.1 / 136-138^{22}$ & 67 \\
\hline $3 f$ & $\mathrm{H}$ & $m$-BrPh & $168.6-170.3 / 169^{42}$ & 66 \\
\hline $3 g$ & $\mathrm{H}$ & $p-\mathrm{BrPh}$ & $156.1-157.2 / 154-156^{22}$ & 75 \\
\hline $3 \mathrm{~h}$ & $\mathrm{H}$ & $m-\mathrm{FPh}$ & $123.3-125.0 / 210.6^{42}$ & 69 \\
\hline $3 \mathbf{i}$ & $\mathrm{H}$ & $p$-FPh & $169.4-170.6 / 167-169^{22}$ & 79 \\
\hline $3 \mathbf{j}$ & $\mathrm{H}$ & $m-\mathrm{MeOPh}$ & $105.7-106.6 / 193^{42}$ & 66 \\
\hline $3 \mathbf{k}$ & $\mathrm{H}$ & $p-\mathrm{MeOPh}$ & $122.9-124.3 / 145-147^{23}$ & 51 \\
\hline 31 & $\mathrm{H}$ & $m-\mathrm{AcPh}$ & $142.7-144.1 /-$ & 48 \\
\hline $3 m$ & $\mathrm{H}$ & $p-\mathrm{NO}_{2} \mathrm{Ph}$ & 203.1-204.6/- & 56 \\
\hline $3 n^{b}$ & $\mathrm{H}$ & $m$-acetylenePh & $183.5-185.4 /-$ & 65 \\
\hline 30 & $\mathrm{Me}$ & $\mathrm{Ph}$ & 120.6-121.8/- & 72 \\
\hline $3 p$ & $\mathrm{H}$ & 3,5-DiMePh & 196.5-197.9/- & 65 \\
\hline $3 q$ & $\mathrm{H}$ & $p-t-\mathrm{BuPh}$ & 144.7-145.9/- & 80 \\
\hline $3 r$ & $\mathrm{H}$ & 3,4-DiClPh & 170.6-171.8/- & 75 \\
\hline $3 \mathrm{~s}$ & $\mathrm{H}$ & 3,5-DiClPh & 216.4-217.8/- & 62 \\
\hline $3 \mathrm{t}^{\mathrm{b}}$ & $\mathrm{H}$ & 3,4-DiFPh & 199.6-200.7/- & 73 \\
\hline $3 \mathbf{u}^{\mathrm{b}}$ & $\mathrm{H}$ & 3,5-DiFPh & 195.2-196.3/- & 61 \\
\hline $3 v$ & $\mathrm{H}$ & $m-\mathrm{CF}_{3} \mathrm{Ph}$ & $121.9-123.0 / 224-225^{43}$ & 53 \\
\hline $3 w^{b}$ & $\mathrm{H}$ & $m-t-\mathrm{BuPh}$ & 108.9-110.1/- & 79 \\
\hline $3 \mathbf{x}^{\mathrm{b}}$ & $\mathrm{H}$ & $p-\mathrm{CF}_{3} \mathrm{Ph}$ & 181.9-182.5/- & 28 \\
\hline
\end{tabular}

asolated yield; ${ }^{b}$ new compounds. 5,6,7,8-tetrahydro-benzothieno[2,3- $d$ ] pyrimidin-4-amines. The proposed mechanism for this rearrangement ${ }^{41}$ is described in Scheme 2.

The structures of all compounds $\mathbf{1}, \mathbf{2}$ and $\mathbf{3 a - x}$ were confirmed by infrared (IR), ${ }^{1} \mathrm{H}$ nuclear magnetic resonance (NMR), ${ }^{13} \mathrm{C}$ NMR spectroscopy, and high-resolution mass spectrometry (HRMS). The IR spectrum of compound $\mathbf{1}$ shows bands at 3444 and $2193 \mathrm{~cm}^{-1}$ corresponding to the $-\mathrm{NH}$ and $-\mathrm{C} \equiv \mathrm{N}$ groups, respectively. For compound $\mathbf{2}$, the IR spectrum shows bands at 2199, 1627 and $1106 \mathrm{~cm}^{-1}$ corresponding to the $-\mathrm{C} \equiv \mathrm{N},-\mathrm{C}=\mathrm{N}$ and $-\mathrm{C}-\mathrm{N}$ groups, respectively. For the sake of the assignment of ${ }^{1} \mathrm{H}$ NMR spectra, we chose compound $\mathbf{3 h}$ as the representative example. The ${ }^{1} \mathrm{H}$ NMR spectrum of the compound $\mathbf{3 h}$ recorded in DMSO- $d_{6}$ shows the multiplet peaks at $\delta$ 7.74-7.60, 7.54-7.43, 7.42-7.30, and 6.96-6.80 assignable to the aryl protons $(-\mathrm{CH})$ and the other multiplets at $\delta 3.24-3.04,2.96-2.74$, and $1.96-1.75$ correspond to alicyclic portions protons $\left(-\mathrm{CH}_{2}\right)$. However, there are two peaks at $\delta 8.38$ and 8.13, probably assigned to 2-position hydrogen on the pyrimidine ring $(-\mathrm{CH})$ and the 4-position at pyrimidine ring $(-\mathrm{NH})$, respectively. In order to solve this assignment problem, D-H exchange technology was applied. One drop of $\mathrm{D}_{2} \mathrm{O}$ was added into the NMR sample of the compound $3 \mathbf{h}$ and it was found that the peak at $\delta$ 8.13 disappeared. Thus, the peak at $\delta 8.13$ was assigned to the hydrogen of $-\mathrm{NH}$ and the other peak at $\delta 8.38$ assigned to the $-\mathrm{CH}$ signal.

To further confirm the structures of these compounds and provide a basis for studies on the structure activity relationships of these compounds, the crystal structures of compounds $\mathbf{3 a}$ and $\mathbf{3} \mathbf{c}$ were determined using single crystal X-ray diffraction. The molecular structures of the two compounds are illustrated in Figure 6. Colorless single crystals of the compound $\mathbf{3 a}(0.35 \times 0.20 \times 0.10 \mathrm{~mm})$ and $3 \mathbf{c}(0.36 \times 0.30 \times 0.17 \mathrm{~mm})$ were selected for $\mathrm{X}$-ray diffraction analysis. The analysis reveals that the

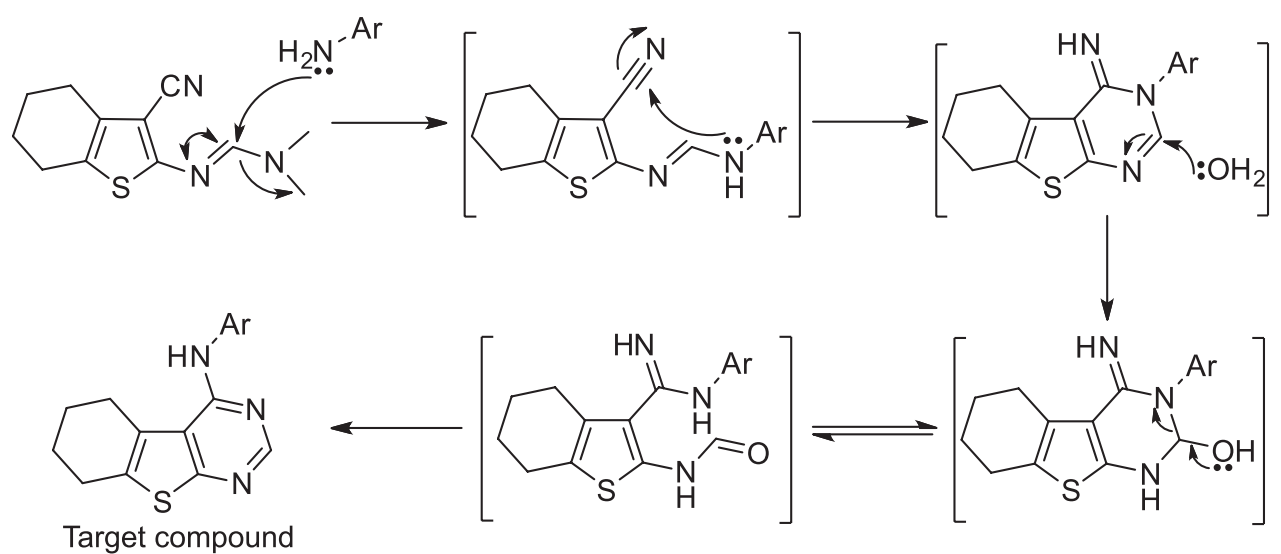

Scheme 2. Proposed mechanism for the Dimroth rearrangement. 


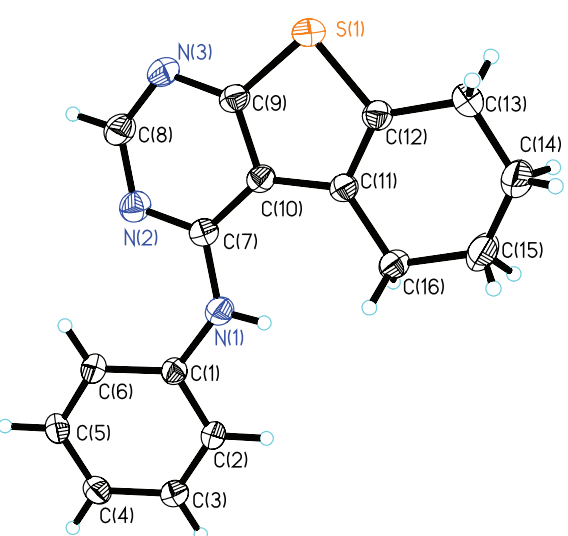

Figure 6. X-ray structures of compounds 3a (left) and $\mathbf{3 c}$ (right).

thieno[2,3- $d]$ pyrimidine ring, which exhibits good coplanar nature, forms a dihedral angle with the benzene ring. The crystal data for 3a: monoclinic, $a=10.7726(5) \AA$, $b=8.6739(4) \AA, c=15.3075(7) \AA, \alpha=90^{\circ}, \beta=106.897(2)^{\circ}$, $\gamma=90^{\circ}, \mathrm{V}=1368.59(11) \AA^{3}$, wavelength $=0.71073 \AA$, space group $\mathrm{P} 2(1) / c, \mathrm{Z}=4$, absorption coefficient $=0.229 \mathrm{~mm}^{-1}$, calculated density $=1.366 \mathrm{mg} \mathrm{cm}^{-3}, \theta$ range for data collection $\left(2.73\right.$ to $\left.27.68^{\circ}\right), \mathrm{F}(000)=592,3072$ unique $\left(R_{\text {int }}=0.0190\right)$ were used in all calculations. The final $R_{1}$ was 0.0810 (I > 2sigma(I)) and $\mathrm{wR}_{2}$ was 0.2202 (all data). The crystal data for 3c: monoclinic, $a=11.8384(3) \AA$, $b=8.6429(2) \AA, c=14.8165(4) \AA, \alpha=90^{\circ}, \beta=98.8890(10)^{\circ}$, $\gamma=90^{\circ}, \mathrm{V}=1497.79(7) \AA^{3}$, wavelength $=0.71073 \AA$, space group $\mathrm{P} 2(1) / c, \mathrm{Z}=4$, absorption coefficient $=0.213 \mathrm{~mm}^{-1}$, calculated density $=1.310 \mathrm{mg} \mathrm{cm}^{-3}, \theta$ range for data collection $\left(1.74\right.$ to $\left.27.41^{\circ}\right), \mathrm{F}(000)=624,3381$ unique $\left(\mathrm{R}_{\text {int }}=0.0201\right)$ were used in all calculations. The final $\mathrm{R}_{1}$ was 0.0707 (I > 2sigma(I)) and $\mathrm{wR}_{2}$ was 0.1982 (all data). Crystallographic data were deposited with the Cambridge Crystallographic Data Centre (see Supplementary Information section below).

\section{Biological activity}

Taking Erlotinib as reference compound, the synthesized compounds $\mathbf{3 a}-\mathbf{x}$ were evaluated for cytotoxic activities of A549, CT26 and HepG2 cell lines using 3-(4,5-dimethylthiazolyl-2)-2,5-diphenyltetrazolium bromide (MTT) assay. The inhibition (at $25 \mu \mathrm{M}$ ) of all target compounds and cytotoxic activities $\left(\mathrm{IC}_{50}\right.$, in $\left.\mu \mathrm{M}\right)$ for selected compounds were summarized in Table 2.

As showed in Table 2, compounds $\mathbf{3 b}, \mathbf{3 d}, \mathbf{3 k}, \mathbf{3} \mathbf{l}, \mathbf{3 q}$, $\mathbf{3 w}$ and $\mathbf{3 x}$ displayed cytotoxic activities against A549 with drug concentration of $25 \mu \mathrm{M}$. Among the seven compounds, compounds $\mathbf{3 b}, \mathbf{3 d}, \mathbf{3 k}$ and $\mathbf{3} \mathbf{w}$ showed lower cytotoxicity (at $25 \mu \mathrm{M})$ than Erlotinib $(25.18 \pm 0.28 \%$ ), with inhibition of $9.21 \pm 0.12,15.88 \pm 0.45,1.87 \pm 0.21$

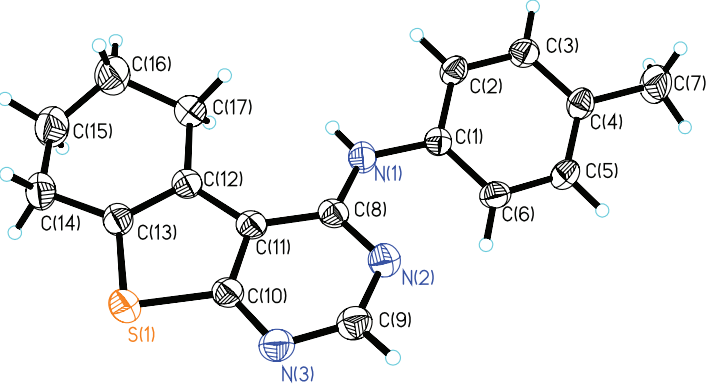

and $17.84 \pm 0.74 \%$, respectively. Compounds $\mathbf{3}$ and $\mathbf{3 x}$ displayed better cytotoxic activity $(37.18 \pm 0.26$ and $55.84 \pm 0.05 \%$ ) compared with the positive drug Erlotinib. Surprisingly, the most outstanding compound is $\mathbf{3 q}$, which displayed best cytotoxic activity against A549 with the inhibition of $85.83 \pm 0.31 \%$.

Besides, most of target compounds $(\mathbf{3 b}, \mathbf{3 d}, \mathbf{3 e}$, 3f, 3g, 3h, 3j, 3m, 3n, 3o, 3p, 3q, 3r, 3s, 3t, 3u, 3v, $\mathbf{3 w}$ and $\mathbf{3 x}$ ) were shown to have cytotoxic activities (at $25 \mu \mathrm{M}$ ) against CT26. In these compounds, the selected six compounds (3e, 3g, 3o, 3p, 3q and 3u) demonstrated inapparent cytotoxic activities compared with the positive control Erlotinib $(24.52 \pm 0.13 \%)$, with inhibition of $2.25 \pm 0.19,1.65 \pm 0.04,2.45 \pm 0.39$, $1.90 \pm 0.20,5.96 \pm 0.51$ and $3.04 \pm 0.59 \%$, respectively. In addition, compounds $\mathbf{3 b}, \mathbf{3 f}, \mathbf{3 h}, \mathbf{3 m}, \mathbf{3 n}$ and $\mathbf{3 s}$ inhibited $14.21 \pm 0.44,13.57 \pm 0.55,14.79 \pm 0.63,19.52 \pm 0.18$, $10.65 \pm 0.23,12.95 \pm 0.08 \%$ of the cytotoxic activities of tested CT26 cell line at compound concentration of $25 \mu \mathrm{M}$, respectively. Besides, compounds $\mathbf{3 d}, \mathbf{3 j}, \mathbf{3 r}, \mathbf{3 t}$, $\mathbf{3 v}, \mathbf{3 w}$ and $\mathbf{3 x}$ outperformed the positive control Erlotinib against CT26 cell line, with inhibition of $40.81 \pm 0.05$, $49.48 \pm 0.06,55.51 \pm 0.62,64.72 \pm 0.37,55.40 \pm 0.17$, $62.16 \pm 0.54$ and $34.08 \pm 0.01 \%$, respectively.

Interestingly, all of synthesized compounds were shown to have cytotoxic activities (at $25 \mu \mathrm{M}$ ) against HepG2. In these compounds, 3m $(8.45 \pm 0.59 \%)$ and 3o $(2.72 \pm 0.35 \%)$ demonstrated the lowest cytotoxic activities. Whereas, ten compounds (3a, 3c, 3f, 3g, 3h, 3k, 3l, 3p, 3s and 3u) depicted moderate cytotoxic effects, with the inhibition of $18.24 \pm 0.38$, $18.72 \pm 0.08,23.38 \pm 0.44,20.64 \pm 0.15,16.28 \pm 0.04$, $19.17 \pm 0.63,17.48 \pm 0.32,21.29 \pm 0.07,14.58 \pm 0.39$ and $19.88 \pm 0.69 \%$, respectively. There are four compounds (3e, 3i, 3n and 3t) which exhibited almost similar cytotoxic activities $(27.37 \pm 0.55,28.69 \pm 0.29,27.49 \pm 0.11$ and $26.81 \pm 0.09 \%$ ) compared with the positive drug 
Table 2. Cytotoxic activities of the compounds 3a-x

\begin{tabular}{|c|c|c|c|c|c|c|c|c|c|}
\hline \multirow{2}{*}{ Compound } & \multirow{2}{*}{$\mathrm{R}^{1}$} & \multirow{2}{*}{$\mathrm{Ar}$} & \multicolumn{3}{|c|}{ Inhibition (at $25 \mu \mathrm{M}$ ) / \% } & \multicolumn{4}{|c|}{$\mathrm{IC}_{50} / \mu \mathrm{M}$} \\
\hline & & & A549 & CT26 & HepG2 & A549 & CT26 & HepG2 & AML-12a \\
\hline 3a & $\mathrm{H}$ & $\mathrm{Ph}$ & $\mathrm{NA}^{\mathrm{b}}$ & NA & $18.24 \pm 0.38$ & $\mathrm{NT}^{\mathrm{c}}$ & NT & NT & NT \\
\hline $3 \mathbf{b}$ & $\mathrm{H}$ & $m-\mathrm{MePh}$ & $9.21 \pm 0.12$ & $14.21 \pm 0.44$ & $33.57 \pm 0.23$ & NT & NT & NT & NT \\
\hline $3 c$ & $\mathrm{H}$ & $p-\mathrm{MePh}$ & NA & NA & $18.72 \pm 0.08$ & NT & NT & NT & NT \\
\hline $3 d$ & $\mathrm{H}$ & $m$-ClPh & $15.88 \pm 0.45$ & $40.81 \pm 0.05$ & $33.94 \pm 0.11$ & NT & $45.71 \pm 0.23$ & $29.81 \pm 0.11$ & NT \\
\hline $3 e$ & $\mathrm{H}$ & $p$-ClPh & NA & $2.25 \pm 0.19$ & $27.37 \pm 0.55$ & NT & NT & NT & NT \\
\hline $3 f$ & $\mathrm{H}$ & $m$-BrPh & NA & $13.57 \pm 0.55$ & $23.38 \pm 0.44$ & NT & NT & NT & NT \\
\hline $3 g$ & $\mathrm{H}$ & $p$-BrPh & NA & $1.65 \pm 0.04$ & $20.64 \pm 0.15$ & NT & NT & NT & NT \\
\hline $3 \mathrm{~h}$ & $\mathrm{H}$ & $m-\mathrm{FPh}$ & NA & $14.79 \pm 0.63$ & $16.28 \pm 0.04$ & NT & NT & NT & NT \\
\hline $3 \mathbf{i}$ & $\mathrm{H}$ & $p-\mathrm{FPh}$ & NA & NA & $28.69 \pm 0.29$ & NT & NT & NT & NT \\
\hline $3 \mathbf{j}$ & $\mathrm{H}$ & $m-\mathrm{MeOPh}$ & NA & $49.48 \pm 0.06$ & $47.98 \pm 0.06$ & NT & $26.92 \pm 0.18$ & $22.35 \pm 0.36$ & NT \\
\hline $3 k$ & $\mathrm{H}$ & $p-\mathrm{MeOPh}$ & $1.87 \pm 0.21$ & NA & $19.17 \pm 0.63$ & NT & NT & NT & NT \\
\hline 31 & $\mathrm{H}$ & $m-\mathrm{AcPh}$ & $37.18 \pm 0.26$ & NA & $17.48 \pm 0.32$ & $70.90 \pm 0.22$ & NT & NT & NT \\
\hline $3 \mathrm{~m}$ & $\mathrm{H}$ & $p-\mathrm{NO}_{2} \mathrm{Ph}$ & NA & $19.52 \pm 0.18$ & $8.45 \pm 0.59$ & NT & NT & NT & NT \\
\hline $3 n$ & $\mathrm{H}$ & $m$-acetylenePh & NA & $10.65 \pm 0.23$ & $27.49 \pm 0.11$ & NT & NT & NT & NT \\
\hline 30 & $\mathrm{Me}$ & $\mathrm{Ph}$ & NA & $2.45 \pm 0.39$ & $2.72 \pm 0.35$ & NT & NT & NT & NT \\
\hline $3 p$ & $\mathrm{H}$ & 3,5-DiMePh & NA & $1.90 \pm 0.20$ & $21.29 \pm 0.07$ & NT & NT & NT & NT \\
\hline $3 q$ & $\mathrm{H}$ & $p-t-\mathrm{BuPh}$ & $85.83 \pm 0.31$ & $5.96 \pm 0.51$ & $61.53 \pm 0.26$ & $16.06 \pm 0.09$ & NT & $15.01 \pm 0.31$ & $>100$ \\
\hline $3 \mathbf{r}$ & $\mathrm{H}$ & 3,4-DiClPh & NA & $55.51 \pm 0.62$ & $35.76 \pm 0.43$ & NT & $22.91 \pm 0.16$ & $36.21 \pm 0.22$ & NT \\
\hline $3 \mathrm{~s}$ & $\mathrm{H}$ & 3,5-DiClPh & NA & $12.95 \pm 0.08$ & $14.58 \pm 0.39$ & NT & NT & NT & NT \\
\hline $3 t$ & $\mathrm{H}$ & 3,4-DiFPh & NA & $64.72 \pm 0.37$ & $26.81 \pm 0.09$ & NT & $19.05 \pm 0.05$ & NT & $95.50 \pm 0.83$ \\
\hline $3 u$ & $\mathrm{H}$ & 3,5-DiFPh & NA & $3.04 \pm 0.59$ & $19.88 \pm 0.69$ & NT & NT & NT & NT \\
\hline $3 v$ & $\mathrm{H}$ & $m-\mathrm{CF}_{3} \mathrm{Ph}$ & NA & $55.40 \pm 0.17$ & $63.64 \pm 0.17$ & NT & $22.39 \pm 0.32$ & $14.02 \pm 0.15$ & $61.66 \pm 0.59$ \\
\hline $3 w$ & $\mathrm{H}$ & $m-t-\mathrm{BuPh}$ & $17.84 \pm 0.74$ & $62.16 \pm 0.54$ & $32.94 \pm 0.54$ & $>100$ & $11.38 \pm 0.44$ & $>100$ & $56.23 \pm 0.71$ \\
\hline $3 \mathbf{x}$ & $\mathrm{H}$ & $p-\mathrm{CF}_{3} \mathrm{Ph}$ & $55.84 \pm 0.05$ & $34.08 \pm 0.01$ & $66.66 \pm 0.03$ & $21.38 \pm 0.69$ & $>100$ & $8.51 \pm 0.52$ & $>100$ \\
\hline Erlotinib $^{\mathrm{d}}$ & - & - & $25.18 \pm 0.28$ & $24.52 \pm 0.13$ & $29.83 \pm 0.21$ & $>100$ & $51.99 \pm 0.19$ & $43.05 \pm 0.09$ & $>100$ \\
\hline
\end{tabular}

${ }^{a} A M L-12$ : murine non-transformed hepatocyte cell line; ${ }^{b} \mathrm{NA}$ : no cytotoxic activity (at $25 \mu \mathrm{M}$ ); ${ }^{\mathrm{c} N T}$ : $\mathrm{IC}_{50}$ value was not measured; ${ }^{\mathrm{d}}$ used as a positive control (standard Erlotinib hydrochloride). A549: human pulmonary carcinoma cell line; CT26: murine BALB/c spontaneous colon adenocarcinoma cell line; HepG2: human hepatocellular liver carcinoma cell line.

Erlotinib (29.83 $\pm 0.21 \%)$. Besides, compounds 3b, 3d, $\mathbf{3 j}$ and $\mathbf{3 w}(33.57 \pm 0.23,33.94 \pm 0.11,47.98 \pm 0.06$ and $32.94 \pm 0.54 \%$ ) showed better cytotoxic activities than the positive drug. The most promising compounds $\mathbf{3 q}, \mathbf{3 v}$ and $\mathbf{3 x}$ exhibited the best cytotoxic effects against HepG2 cell line with inhibition of $61.53 \pm 0.26,63.64 \pm 0.17$ and $66.66 \pm 0.03 \%$, respectively.

According to the analysis of above activity data, five compounds (3b, 3d, 3q, 3w and $\mathbf{3 x}$ ) exhibited cytotoxic activities against all selected tumor cell lines (A549, CT26 and HepG2). Especially, compound $\mathbf{3 q}$ depicted better cytotoxic effects against A549 and HepG2 cell lines. In addition, $\mathbf{3 t}$ and $\mathbf{3 x}$ displayed the best cytotoxic effects against CT26 and HepG2 cell lines, respectively.

Three (3l, 3q and $\mathbf{3 x}$ ), seven (3d, 3j, 3r, 3t, 3v, 3w and $\mathbf{3 x}$ ) and seven compounds (3d, 3j, 3q, 3r, 3v, 3w and 3x), which have better cytotoxic activities compared to Erlotinib (at $25 \mu \mathrm{M}$ ), were subsequently severally selected to investigate the $\mathrm{IC}_{50}$ values (Table 2 ) of cytotoxic activity against A549, CT26 and HepG2 cell lines, respectively.

The present study investigated the effect of several different structures and from the results of cytotoxic activities of the compounds, the following preliminary structure-activity relationships can be derived:

(i) The compound $\mathbf{3 q}$ showed the most outstanding cytotoxic activity $\left(\mathrm{IC}_{50}=16.06 \pm 0.09 \mu \mathrm{M}\right)$ and the next most promising compound was $\mathbf{3 x}$, which displayed good cytotoxic activity $\left(\mathrm{IC}_{50}=21.38 \pm 0.69 \mu \mathrm{M}\right)$ against $\mathrm{A} 549$ cell line. Compound $\mathbf{3 1}$ showed moderate cytotoxic effects $\left(\mathrm{IC}_{50}=70.90 \pm 0.22 \mu \mathrm{M}\right.$ ). Based on this (Figure 7), it is possible to surmise: when introducing a group with strong electron-donating $(\mathbf{3 q}, \mathrm{Ar}=p-t-\mathrm{BuPh})$ or strong electron- 
withdrawing $\left(3 \mathbf{x}, \mathrm{Ar}=p-\mathrm{CF}_{3} \mathrm{Ph}\right)$ into the 4-position, the cytotoxic activity (A549) of compounds could be boosted. It was also observed that the presence of $\pi-\pi$ conjugate effect $(\mathbf{3 l}, \mathrm{Ar}=m-\mathrm{AcPh})$ played an important role in the cytotoxic effect.

(ii) Subsequently, the introduction of strong electronwithdrawing group $(\mathbf{3 r}, \mathbf{3 t}$ and $\mathbf{3 v}, \mathrm{Ar}=3,4-\mathrm{DiClPh}$, 3,4-DiFPh and $m-\mathrm{CF}_{3} \mathrm{Ph}$, respectively) led to a better cytotoxic activity $\left(\mathrm{IC}_{50}=22.91 \pm 0.16,19.05 \pm 0.05\right.$, $22.39 \pm 0.32 \mu \mathrm{M}$, respectively) against CT26 cell line (Figure 8). Furthermore, the introduction of strong electron-donating $(3 \mathbf{w}, \mathrm{Ar}=m-t-\mathrm{BuPh})$ also improves the cytotoxic effect $\left(\mathrm{IC}_{50}=11.38 \pm 0.44 \mu \mathrm{M}\right)$ of the compound. Another interesting phenomenon was found that when introducing a double chlorine or a double fluorine (3r, $\mathrm{Ar}=3,4-\mathrm{DiClPh} ; \mathbf{3 t}, \mathrm{Ar}=3,4-\mathrm{DiFPh}$ ) into the 3,4-position, the resulting activity was higher than that of compounds $3 \mathbf{s}$ and $3 \mathbf{u}(\mathrm{Ar}=3,5-\mathrm{DiClPh} ; \mathrm{Ar}=3,5-\mathrm{DiFPh})$ with drug concentration of $25 \mu \mathrm{M}$. Besides, compounds $\mathbf{3 d}$ and $\mathbf{3 j}$ also displayed good cytotoxic activity $\left(\mathrm{IC}_{50}=45.71 \pm 0.23\right.$ and $26.92 \pm 0.18 \mu \mathrm{M}$, respectively) against CT26 cell line, which might be due to the presence of $p-\pi$ conjugate effect $(\mathbf{3 j}, \mathrm{Ar}=m-\mathrm{MeOPh})$.

(iii) Meanwhile, compounds substituted with bulky electron-withdrawing $\left(\mathbf{3 x}, \mathrm{Ar}=p-\mathrm{CF}_{3} \mathrm{Ph} ; \mathbf{3 v}, \mathrm{Ar}=m-\mathrm{CF}_{3} \mathrm{Ph}\right)$ or strong electron-donating groups $(\mathbf{3 q}, \mathrm{Ar}=p-t-\mathrm{BuPh})$ exhibited far superior cytotoxic activity $\left(\mathrm{IC}_{50}=8.51 \pm 0.52\right.$, $14.02 \pm 0.15$ and $15.01 \pm 0.31 \mu \mathrm{M}$, respectively) than other compounds (Figure 9). Moreover, the cytotoxic activity against HepG2 cell line was enhanced because of $p-\pi$ conjugate effect (3d, $\mathrm{Ar}=m-\mathrm{ClPh} ; \mathbf{3 j}, \mathrm{Ar}=m-\mathrm{MeOPh})$, with $\mathrm{IC}_{50}$ values of $29.81 \pm 0.11$ and $22.35 \pm 0.36 \mu \mathrm{M}$, respectively.

(iv) To sum up, all of the synthesized compounds exhibited cytotoxic activities against HepG2 cell line with drug concentration of $25 \mu \mathrm{M}$, most of target compounds were shown to have cytotoxic activities against CT26 cell line, while only seven compounds demonstrated cytotoxic activities against A549 cell line. In general, it was found that all synthesized compounds showed significant selective cytotoxic effect against the HepG2.

The effects of selected compounds $\left(\mathrm{IC}_{50}\right.$ values of selected compounds $>\mathrm{IC}_{50}$ values of Erlotinib against A549, CT26 and HepG2) on cell viability were assessed. The detailed results are provided in Figures 10, 11 and 12, respectively.

In relation to selectivity index (SI), Erlotinib showed SI $>1.92$ and 2.32 for CT26 and HepG2 cells (Table 3, entry 1), respectively. Compound $\mathbf{3 v}$ showed moderate SI $=2.75$ for CT26 cell line (Table 3, entry 4) and

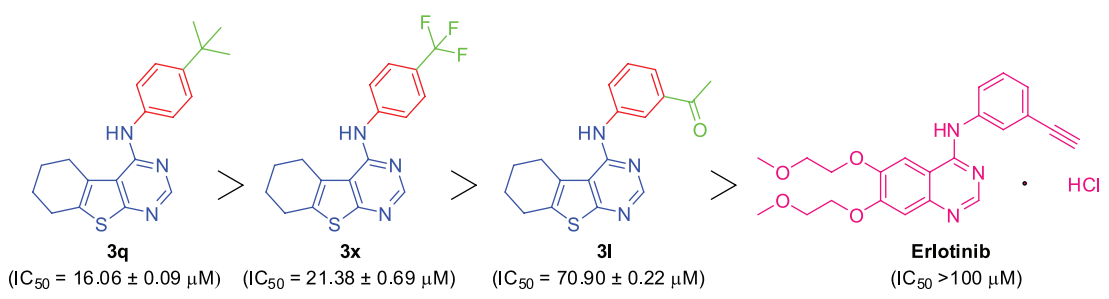

Figure 7. Comparison of cytotoxic activities ( $\mathrm{IC}_{50}$ values) against $\mathrm{A} 549$ cell line.

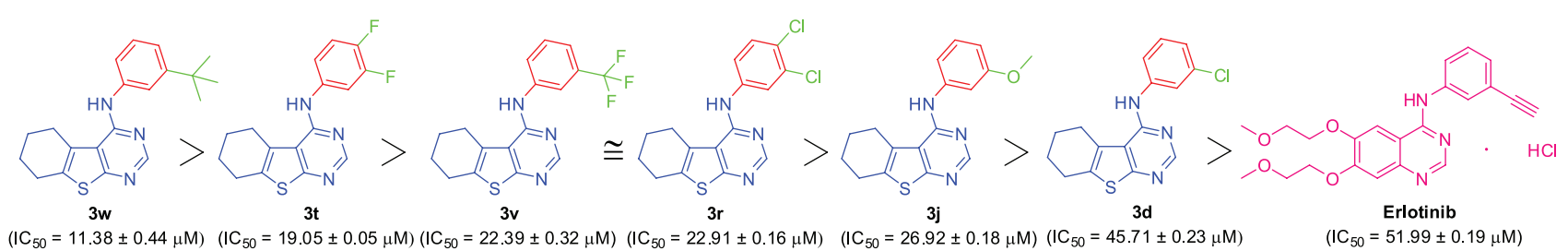

Figure 8. Comparison of cytotoxic activities ( $\mathrm{IC}_{50}$ values) against CT26 cell line.

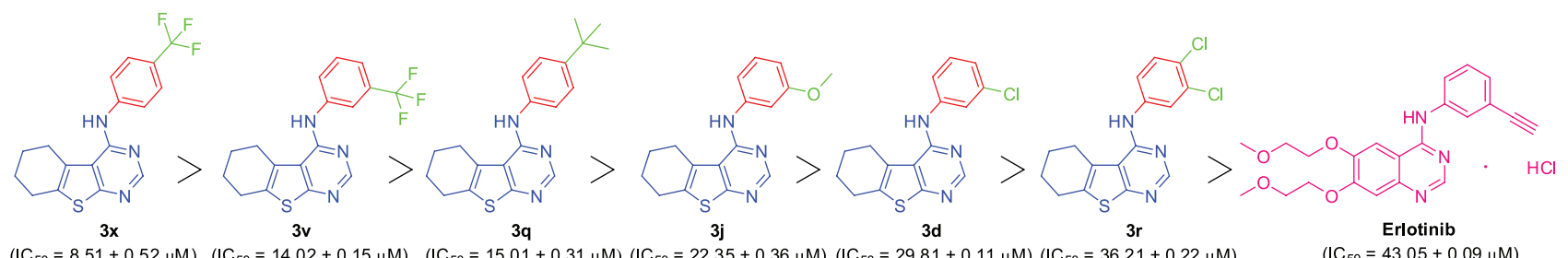

$\left(I C_{50}=8.51 \pm 0.52 \mu \mathrm{M}\right) \quad\left(I C_{50}=14.02 \pm 0.15 \mu \mathrm{M}\right) \quad\left(I C_{50}=15.01 \pm 0.31 \mu \mathrm{M}\right) \quad\left(I C_{50}=22.35 \pm 0.36 \mu \mathrm{M}\right)\left(\mathrm{IC}_{50}=29.81 \pm 0.11 \mu \mathrm{M}\right)\left(I \mathrm{C}_{50}=36.21 \pm 0.22 \mu \mathrm{M}\right) \quad\left(I C_{50}=43.05 \pm 0.09 \mu \mathrm{M}\right)$

Figure 9. Comparison of cytotoxic activities ( $\mathrm{IC}_{50}$ values) against $\mathrm{HepG} 2$ cell line. 


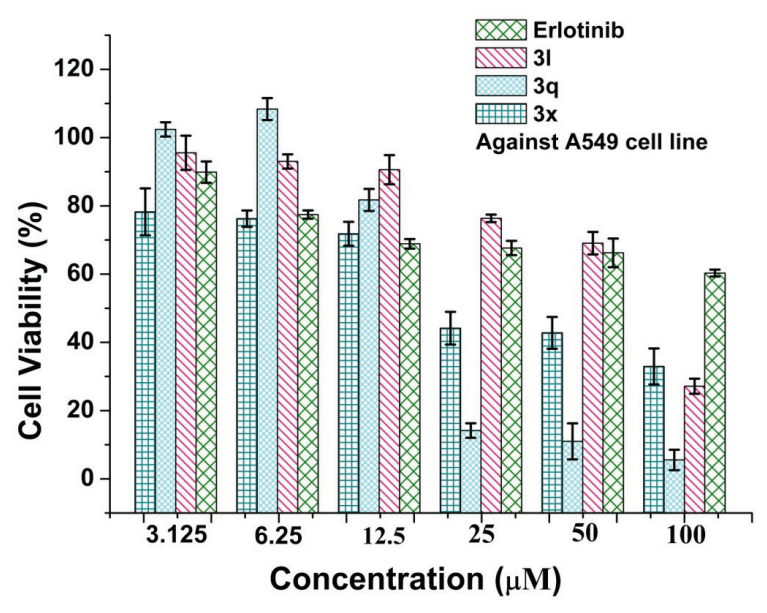

Figure 10. Cell viability of selected compounds toward A549 cell line.

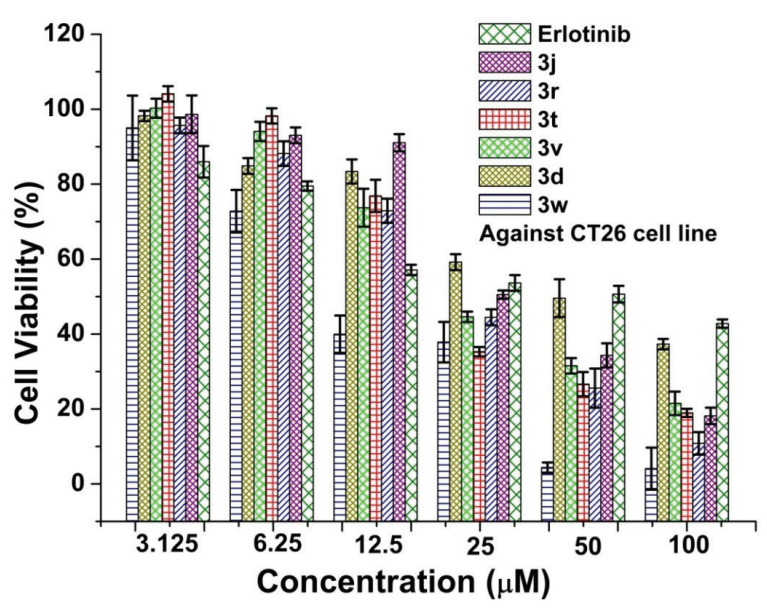

Figure 11. Cell viability of selected compounds toward CT26 cell line.

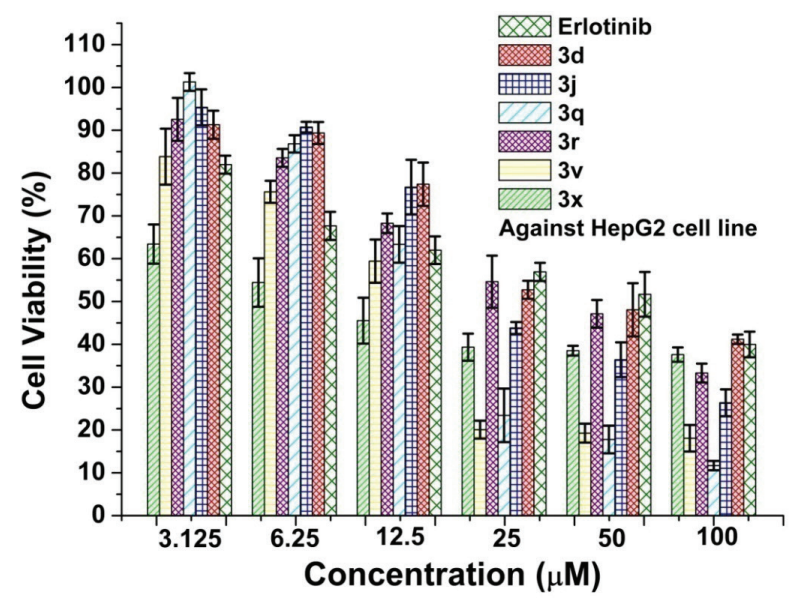

Figure 12. Cell viability of selected compounds toward HepG2 cell line.

compounds $\mathbf{3 t}, \mathbf{3 w}$ and $\mathbf{3 v}$ showed good selectivity index for CT26 cell line (Table 3, entry 3, 5; SI $=5.01,4.94$ ) and $\mathrm{HepG} 2$ cell line (Table 3, entry 4; SI $=4.40$ ). Besides, compound 3x also displayed good SI $>4.68$ for A549 cell line and lower cytotoxicity (Table 3 , entry 6 ), with SI > 11.75 for HepG2 cell line.
Table 3. Selectivity index (SI) ${ }^{\text {a }}$ for selected compounds

\begin{tabular}{lcccc}
\hline & & \multicolumn{3}{c}{ Selectivity index } \\
\cline { 3 - 5 } entry & Compound & AML-12 vs. & AML-12 vs. & AML-12 vs. \\
& & A549 & CT26 & HepG2 \\
\hline 1 & Erlotinib $^{\mathrm{b}}$ & NC $^{\mathrm{c}}$ & $>1.92$ & $>2.32$ \\
2 & $\mathbf{3 q}$ & $>6.23$ & $\mathrm{NC}$ & $>6.66$ \\
3 & $\mathbf{3 t}$ & $\mathrm{NC}$ & 5.01 & $\mathrm{NC}$ \\
4 & $\mathbf{3 v}$ & $\mathrm{NC}$ & 2.75 & 4.40 \\
5 & $\mathbf{3 w}$ & $\mathrm{NC}$ & 4.94 & $\mathrm{NC}$ \\
6 & $\mathbf{3 x}$ & $>4.68$ & $\mathrm{NC}$ & $>11.75$ \\
\hline
\end{tabular}

${ }^{a} \mathrm{SI}$, selectivity index: $\mathrm{IC}_{50}$ on normal cells / $\mathrm{IC}_{50}$ on cancer cells; bpositive control: standard Erlotinib hydrochloride of AML-12 cell; ${ }^{\mathrm{C}} \mathrm{NC}$ : not calculated. AML-12: murine non-transformed hepatocyte cell line; A549: human pulmonary carcinoma cell line; CT26: murine BALB/c spontaneous colon adenocarcinoma cell line; HepG2: human hepatocellular liver carcinoma cell line.

\section{Conclusions}

In conclusion, we have synthesized and evaluated a library of thieno[2,3-d]pyrimidine derivatives. Amongst these compounds (3a-x), 3q was found to have better cytotoxic activity with reference to the standard Erlotinib hydrochloride (Tarceva ${ }^{\mathrm{TM}}$ ) against A549 $\left(\mathrm{IC}_{50}=16.06 \pm 0.09 \mu \mathrm{M}\right)$ and HepG2 $\left(\mathrm{IC}_{50}=15.01 \pm 0.31 \mu \mathrm{M}\right)$ cell lines. Especially, 3w and 3x showed best cytotoxic effects against CT26 $\left(\mathrm{IC}_{50}=11.38 \pm 0.44 \mu \mathrm{M}\right)$ and $\mathrm{HepG} 2\left(\mathrm{IC}_{50}=8.51 \pm 0.52 \mu \mathrm{M}\right)$ cell lines, respectively. Compound $\mathbf{3 x}$ also showed good selectivity index (SI > 11.75). Furthermore, additional preliminary structure-activity relationships could be responsible for the found potent and selective activity of new thieno[2,3- $d$ ]pyrimidine compounds. Besides, the synthesized compounds (3a-x) would be evaluated for their enzyme activities and protein activities in following work and the more complete structure-activity relationships would be disclosed.

\section{Experimental}

\section{General remarks}

All melting points were measured on an MP90 apparatus and are uncorrected. IR spectra were recorded in a VERTEX 80/Raman II (Bruker, Switzerland, $\mathrm{KBr}$ pellets). The ${ }^{1} \mathrm{H}$ NMR (400 MHz) and ${ }^{13} \mathrm{C}$ NMR $(100 \mathrm{MHz})$ spectra were recorded in an Avance III HD (Bruker, Switzerland) spectrometer with tetramethylsilane (TMS) as internal reference in $\mathrm{CDCl}_{3}$ or dimethyl sulfoxide (DMSO- $d_{6}$ ) as the solvent. Only discrete or characteristic signals for the ${ }^{1} \mathrm{H}$ NMR are reported. 
The MS spectra were obtained on a Triple-TOFTM $5600+$ spectrometer (AB SCIEX, USA). An X-ray crystallographic analysis was performed with a Bruker SMART APEX II (Bruker, Switzerland). The structure of the single crystals was refined by a Shelx- $97 .{ }^{44}$ All reactions were monitored by thin layer chromatography (TLC) with ethyl acetate:hexane (1:4, v/v) as the eluent. All reagents and solvents had been purchased from commercial sources and commonly purified before their usage.

General procedure for preparation of 2-amino-4,5,6,7-tetrahydrobenzo[b]thiophene-3-carbonitrile (1)

Cyclohexanone $(0.98 \mathrm{~g}, 10 \mathrm{mmol})$, malononitrile $(0.66 \mathrm{~g}, 10 \mathrm{mmol})$, sulfur powder $(0.35 \mathrm{~g}, 11.0 \mathrm{mmol})$, $\mathrm{K}_{2} \mathrm{CO}_{3}(0.28 \mathrm{~g}, 2.0 \mathrm{mmol})$ and $20 \mathrm{~mL}$ of dry ethanol were mixed and placed in a $50 \mathrm{~mL}$ pressure tube. The mixture was subjected to microwave irradiation (CEM Explorer Hybrid, USA, $100 \mathrm{~W}, 200 \mathrm{psi}, 85^{\circ} \mathrm{C}$ ) for $15 \mathrm{~min}$. After the reaction, the insoluble material was filtered out, and the solvent was removed through evaporation under reduced pressure. The crude product was washed with water and recrystallized from ethanol to give yellowish crystals of $1.69 \mathrm{~g}(9.50 \mathrm{mmol})$, in $95 \%$ yield; $\mathrm{mp} 146.8-148.0{ }^{\circ} \mathrm{C}$; ${ }^{1} \mathrm{H}$ NMR $\left(400 \mathrm{MHz}, \mathrm{CDCl}_{3}\right) \delta 4.61(\mathrm{~s}, 2 \mathrm{H}), 2.59-2.39$ (m, 4H), 1.90-1.69 (m, 4H); ${ }^{13} \mathrm{C}$ NMR (100 MHz, $\mathrm{CDCl}_{3}$ ) $\delta$ 159.87, 132.37, 120.67, 115.43, 88.82, 24.52, 24.13, 23.37, 22.12; IR (KBr) v / cm ${ }^{-1} 3444,3327,2907,2193$, 1618, 1520; HRMS (ESI) $\mathrm{m} / z$, calcd. for $\mathrm{C}_{9} \mathrm{H}_{10} \mathrm{~N}_{2} \mathrm{~S}$ $[\mathrm{M}+\mathrm{H}]^{+}:$179.0637; found: 179.0638 .

Preparation of $N^{\prime}$-(3-cyano-4,5,6,7-tetrahydrobenzo [b]thiophen-2-yl)- $N, N$-dimethylformimidamide (2)

Compound 1 (1.78 g, $10 \mathrm{mmol})$ and DMF-DMA (3.57 g, $30 \mathrm{mmol})$ were added into a 1-necked $20 \mathrm{~mL}$ pressure tube, and then the mixture was subjected to microwave irradiation (CEM Explorer Hybrid, USA, $100 \mathrm{~W}, 200 \mathrm{psi}, 78^{\circ} \mathrm{C}$ ) for $5 \mathrm{~min}$. After the reaction, the DMF-DMA was evaporated in vacuum and the crude compound was re-crystallized from ethyl acetate to give the target compound of $2.29 \mathrm{~g}(9.80 \mathrm{mmol})$, in $98 \%$ yield; mp 125.8-126.9 ${ }^{\circ} \mathrm{C} ;{ }^{1} \mathrm{H}$ NMR $\left(400 \mathrm{MHz}, \mathrm{CDCl}_{3}\right) \delta 7.67$ $(\mathrm{s}, 1 \mathrm{H}), 3.08(\mathrm{~s}, 6 \mathrm{H}), 2.61-2.52(\mathrm{~m}, 4 \mathrm{H}), 1.87-1.74(\mathrm{~m}$, $4 \mathrm{H}) ;{ }^{13} \mathrm{C}$ NMR $\left(100 \mathrm{MHz}, \mathrm{CDCl}_{3}\right) \delta 164.07,153.85$, 133.25, 124.39, 116.30, 97.11, 40.59, 34.95, 24.75, 24.44, 23.39, 22.27; IR (KBr) v / cm ${ }^{-1} 2930,2199,1627,1508$, 1106; HRMS (ESI) $m / z$, calcd. for $\mathrm{C}_{12} \mathrm{H}_{15} \mathrm{~N}_{3} \mathrm{~S}[\mathrm{M}+\mathrm{H}]^{+}$: 234.1059; found: 234.1099 .
Preparation of $\mathrm{N}$-aryl-5,6,7,8-tetrahydrobenzo[4,5]thieno [2,3-d]pyrimidin-4-amines (3a-x)

Compound 2 (2.33 g, $10 \mathrm{mmol})$, appropriate aniline $(11 \mathrm{mmol})$ and acetic acid $(8 \mathrm{~mL})$ as the solvent as well as catalyst were added into a 1-necked $20 \mathrm{~mL}$ pressure tube at room temperature. The mixture was subjected to microwave irradiation (CEM Explorer Hybrid, USA, 100 W, 200 psi, $90^{\circ} \mathrm{C}$ ) for $10 \mathrm{~min}$. After reaction, the acetic acid was evaporated in a vacuum and the crude product was recrystallized from ethyl acetate to give target compounds (3a-x).

$N$-Phenyl-5,6,7,8-tetrahydrobenzo[4,5]thieno[2,3-d]pyrimidin4-amine (3a)

${ }^{1} \mathrm{H}$ NMR $\left(400 \mathrm{MHz}, \mathrm{DMSO}-d_{6}\right) \delta 8.38(\mathrm{~s}, 1 \mathrm{H}), 8.13(\mathrm{~s}$, $1 \mathrm{H}), 7.67-7.65(\mathrm{~m}, 2 \mathrm{H}), 7.39-7.32(\mathrm{~m}, 2 \mathrm{H}), 7.13-7.07(\mathrm{~m}$, $1 \mathrm{H}), 3.14(\mathrm{~m}, 2 \mathrm{H}), 2.83(\mathrm{~m}, 2 \mathrm{H}), 1.86(\mathrm{~m}, 4 \mathrm{H}) ;{ }^{13} \mathrm{C} \mathrm{NMR}$ $\left(100 \mathrm{MHz}, \mathrm{DMSO}-d_{6}\right) \delta 166.24,155.35,152.56,139.67$, $133.41,128.90,127.09,123.80,122.58,117.25,25.83$, 25.55, 22.63, 22.48; IR (KBr) v / $\mathrm{cm}^{-1} 3426,3044,2921$, 1602, 1563, 1500, 1440, 1213, 972, 748, 697, 498; HRMS (ESI) $m / z$, calcd. for $\mathrm{C}_{16} \mathrm{H}_{15} \mathrm{~N}_{3} \mathrm{~S}[\mathrm{M}+\mathrm{H}]^{+}: 282.1059$; found: 282.1063 .

$N$-(m-Tolyl)-5, 6, 7, 8-tetrahydrobenzo[4,5]thieno [2,3-d]pyrimidin-4-amine (3b)

${ }^{1} \mathrm{H}$ NMR (400 MHz, $\left.\mathrm{CDCl}_{3}\right) \delta 8.49(\mathrm{~s}, 1 \mathrm{H}), 7.50-7.40$ $(\mathrm{m}, 2 \mathrm{H}), 7.30-7.22(\mathrm{~m}, 1 \mathrm{H}), 7.11(\mathrm{~s}, 1 \mathrm{H}), 6.96(\mathrm{~d}, J 7.5 \mathrm{~Hz}$, $1 \mathrm{H}), 3.12-3.02(\mathrm{~m}, 2 \mathrm{H}), 2.90-2.81(\mathrm{~m}, 2 \mathrm{H}), 2.39$ (s, 3H), 2.06-1.88 (m, 4H); ${ }^{13} \mathrm{C}$ NMR (100 MHz, $\left.\mathrm{CDCl}_{3}\right) \delta 166.23$, $155.10,152.65,139.00,138.35,134.59,128.93,124.94$, $124.80,121.93,118.51,116.65,26.56,25.56,22.60$, 22.44, 21.59; IR (KBr) v / $\mathrm{cm}^{-1} 3450,2944,1610,1565$, 1482, 1372, 1165, 777, 517; HRMS (ESI) $\mathrm{m} / 2$, calcd. for $\mathrm{C}_{17} \mathrm{H}_{17} \mathrm{~N}_{3} \mathrm{~S}[\mathrm{M}+\mathrm{H}]^{+}$: 296.1216; found: 296.1219 .

$N$-(p-Tolyl)-5, 6, 7, 8-tetrahydrobenzo[4,5]thieno [2,3- $d]$ pyrimidin-4-amine (3c)

${ }^{1} \mathrm{H}$ NMR $\left(400 \mathrm{MHz}, \mathrm{CDCl}_{3}\right) \delta 8.46(\mathrm{~s}, 1 \mathrm{H}), 7.50(\mathrm{~d}$, $J 5.5 \mathrm{~Hz}, 2 \mathrm{H}), 7.19(\mathrm{~d}, J 8.2 \mathrm{~Hz}, 2 \mathrm{H}), 7.07(\mathrm{~s}, 1 \mathrm{H}), 3.16-2.98$ (m, 2H), 2.94-2.74 (m, 2H), 2.35 (s, 3H), 2.11-1.80 (m, 4H); ${ }^{13} \mathrm{C}$ NMR $\left(100 \mathrm{MHz}, \mathrm{CDCl}_{3}\right) \delta 166.15,155.31,152.71$, 135.70, 134.42, 133.97, 129.62, 124.87, 121.86, 116.53, 26.56, 25.55, 22.60, 22.45, 20.94; IR (KBr) v / $\mathrm{cm}^{-1} 3421$, 2918, 1599, 1560, 1505, 1222, 977, 815, 496; HRMS (ESI) $m / z$, calcd. for $\mathrm{C}_{17} \mathrm{H}_{17} \mathrm{~N}_{3} \mathrm{~S}[\mathrm{M}+\mathrm{H}]^{+}:$296.1216; found: 296.1212 .

$\mathrm{N}$-(3-Chlorophenyl)-5,6,7,8-tetrahydrobenzo[4,5]thieno [2,3-d]pyrimidin-4-amine (3d)

${ }^{1} \mathrm{H}$ NMR (400 MHz, DMSO- $\left.d_{6}\right) \delta 8.45(\mathrm{~s}, 1 \mathrm{H},-\mathrm{CH})$, 
$8.24(\mathrm{~s}, 1 \mathrm{H}), 7.86(\mathrm{t}, J 2.0 \mathrm{~Hz}, 1 \mathrm{H}), 7.73-7.53(\mathrm{~m}, 1 \mathrm{H}), 7.36$ (t, $J 8.1 \mathrm{~Hz}, 1 \mathrm{H}), 7.26-6.98(\mathrm{~m}, 1 \mathrm{H}), 3.25-3.03(\mathrm{~m}, 2 \mathrm{H})$, 2.98-2.69 (m, 2H), 1.93-1.68 (m, 4H); ${ }^{13} \mathrm{C} \mathrm{NMR} \mathrm{(100} \mathrm{MHz,}$ DMSO- $\left.d_{6}\right) \delta 166.54,154.82,152.37,141.30,133.90$, 133.21, 130.41, 126.96, 123.11, 121.49, 120.55, 117.53, 25.74, 25.56, 22.61, 22.42; IR (KBr) v / $\mathrm{cm}^{-1} 3444,2944$, 1599, 1558, 1502, 1437, 1219, 1129, 984, 875, 762, 679, 515; HRMS (ESI) $m / z$, calcd. for $\mathrm{C}_{16} \mathrm{H}_{14} \mathrm{ClN}_{3} \mathrm{~S}[\mathrm{M}+\mathrm{H}]^{+}$: 316.0670; found: 316.0668 .

$N$-(4-Chlorophenyl)-5,6,7,8-tetrahydrobenzo[4,5]thieno [2,3-d]pyrimidin-4-amine (3e)

${ }^{1} \mathrm{H}$ NMR $\left(400 \mathrm{MHz}, \mathrm{CDCl}_{3}\right) \delta 8.48(\mathrm{~s}, 1 \mathrm{H}), 7.73-7.50$ (m, 2H), 7.44-7.29 (m, 2H), 7.11 (s, 1H), 3.17-2.95 (m, 2H), 2.96-2.74 (m, 2H), 2.07-1.86 (m, 4H); ${ }^{13} \mathrm{C} \mathrm{NMR} \mathrm{(100} \mathrm{MHz,}$ $\left.\mathrm{CDCl}_{3}\right) \delta 166.46,154.76,152.43,137.09,135.09,129.06$, $128.94,124.59,122.48,116.70,26.58,25.57,22.57$, 22.41; IR (KBr) v / $\mathrm{cm}^{-1} 3451,2933,1606,1560,1495$, 1434, 1092, 979, 832, 497; HRMS (ESI) $\mathrm{m} / \mathrm{z}$, calcd. for $\mathrm{C}_{16} \mathrm{H}_{14} \mathrm{ClN}_{3} \mathrm{~S}[\mathrm{M}+\mathrm{H}]^{+}:$316.0670; found: 316.0673 .

$N$-(3-Bromophenyl)-5,6,7,8-tetrahydrobenzo[4,5]thieno [2,3-d]pyrimidin-4-amine (3f)

${ }^{1} \mathrm{H}$ NMR $\left(400 \mathrm{MHz}, \mathrm{CDCl}_{3}\right) \delta 8.44(\mathrm{~s}, 1 \mathrm{H}), 7.87(\mathrm{~d}$, $J 1.8 \mathrm{~Hz}, 1 \mathrm{H}), 7.53-7.46(\mathrm{~m}, 1 \mathrm{H}), 7.18-7.10(\mathrm{~m}, 2 \mathrm{H}), 7.07$ (s, 1H), 3.03-2.94 (m, 2H), 2.83-2.73 (m, 2H), 1.99-1.81 $(\mathrm{m}, 4 \mathrm{H}) ;{ }^{13} \mathrm{C}$ NMR $\left(100 \mathrm{MHz}, \mathrm{CDCl}_{3}\right) \delta 166.15,154.55$, $152.17,139.85,135.39,130.27,126.71,124.55,123.70$, $122.65,119.39,116.79,26.53,25.57,22.53,22.38$; IR $(\mathrm{KBr}) \mathrm{v} / \mathrm{cm}^{-1} 3446,2945,1597,1500,1469,1439,1378$, 1131, 992, 763, 668, 520; HRMS (ESI) $\mathrm{m} / \mathrm{z}$, calcd. for $\mathrm{C}_{16} \mathrm{H}_{14} \mathrm{BrN}_{3} \mathrm{~S}[\mathrm{M}-\mathrm{H}]^{-}: 358.0019$; found: 358.0020 .

$\mathrm{N}$-(4-Bromophenyl)-5,6,7,8-tetrahydrobenzo[4,5]thieno [2,3-d]pyrimidin-4-amine (3g)

${ }^{1} \mathrm{H}$ NMR (400 MHz, $\left.\mathrm{CDCl}_{3}\right) \delta 8.41(\mathrm{~s}, 1 \mathrm{H}), 7.59-7.44$ (m, 2H), 7.44-7.35 (m, 2H), 7.06 (s, 1H), 3.04-2.95 (m, 2H), 2.84-2.72 (m, 2H), 2.00-1.79 (m, 4H); ${ }^{13} \mathrm{C} \mathrm{NMR}(100 \mathrm{MHz}$, $\left.\mathrm{CDCl}_{3}\right) \delta 166.04,154.69,152.17,137.53,135.26,131.99$, $124.61,122.77,116.76,116.54,26.54,25.57,22.54$, 22.39; IR (KBr) v / $\mathrm{cm}^{-1} 3451,2932,1605,1558,1496$, 1432, 1222, 1125, 829, 803; HRMS (ESI) $\mathrm{m} / z$, calcd. for $\mathrm{C}_{16} \mathrm{H}_{14} \mathrm{BrN}_{3} \mathrm{~S}[\mathrm{M}-\mathrm{H}]^{-:}$: 358.0019; found: 358.0017 .

$N$-(3-Fluorophenyl)-5,6,7,8-tetrahydrobenzo[4,5]thieno [2,3-d]pyrimidin-4-amine (3h)

${ }^{1} \mathrm{H}$ NMR $\left(400 \mathrm{MHz}, \mathrm{DMSO}-d_{6}\right) \delta 8.46(\mathrm{~s}, 1 \mathrm{H}), 8.28(\mathrm{~s}$, $1 \mathrm{H}), 7.74-7.60(\mathrm{~m}, 1 \mathrm{H}), 7.54-7.43(\mathrm{~m}, 1 \mathrm{H}), 7.42-7.30(\mathrm{~m}$, $1 \mathrm{H}), 6.96-6.80(\mathrm{~m}, 1 \mathrm{H}), 3.24-3.04(\mathrm{~m}, 2 \mathrm{H}), 2.96-2.74(\mathrm{~m}$, 2H), $1.96-1.75$ (m, 4H); ${ }^{1} \mathrm{H}$ NMR (400 MHz, DMSO- $d_{6}-$ $\left.\mathrm{D}_{2} \mathrm{O}\right) \delta 8.44(\mathrm{~s}, 1 \mathrm{H}), 7.72-7.63(\mathrm{~m}, 1 \mathrm{H}), 7.50-7.43(\mathrm{~m}, 1 \mathrm{H})$,
7.41-7.32 (m, 1H), 6.94-6.84 (m, 1H), 3.20-3.04 (m, 2H), 2.90-2.76 (m, 2H), 1.94-1.77 (m, 4H); ${ }^{13} \mathrm{C} \mathrm{NMR}(100 \mathrm{MHz}$, DMSO- $\left.d_{6}\right) \delta 166.47,163.73,161.34,154.78,152.38$, 141.44, 134.06, 130.42, 126.98, $117.72(\mathrm{~d}, J 2.6 \mathrm{~Hz})$, 117.56, 109.91, 108.63, 25.68, 25.55, 22.58, 22.41; IR $(\mathrm{KBr}) \mathrm{v} / \mathrm{cm}^{-1} 3452,2936,1611,1577,1506,1447,1377$, 1139, 990, 763; HRMS (ESI) $\mathrm{m} / 2$, calcd. for $\mathrm{C}_{16} \mathrm{H}_{14} \mathrm{FN}_{3} \mathrm{~S}$ $[\mathrm{M}-\mathrm{H}]^{-}:$298.0820; found: 298.0825 .

$N$-(4-Fluorophenyl)-5,6,7,8-tetrahydrobenzo[4,5]thieno [2,3-d]pyrimidin-4-amine (3i)

${ }^{1} \mathrm{H}$ NMR (400 MHz, DMSO- $\left.d_{6}\right) \delta 8.35$ (s, 1H), 8.13 (s, $1 \mathrm{H}), 7.70-7.59(\mathrm{~m}, 2 \mathrm{H}), 7.24-7.14(\mathrm{~m}, 2 \mathrm{H}), 3.16-3.07$ (m, 2H), 2.87-2.76 (m, 2H), 1.91-1.80 (m, 4H); ${ }^{13} \mathrm{C}$ NMR $\left(100 \mathrm{MHz}, \mathrm{DMSO}-d_{6}\right) \delta 166.21,160.11,157.73,155.46$, 152.54, 135.90 (d, J 2.6 Hz), 133.32, 127.07, 125.02, $117.03,115.55,115.33,25.85,25.53,22.63,22.46$; IR $(\mathrm{KBr}) \vee / \mathrm{cm}^{-1} 3428,2921,1614,1569,1504,1438$, 1205, 1128, 955; HRMS (ESI) $\mathrm{m} / z$, calcd. for $\mathrm{C}_{16} \mathrm{H}_{14} \mathrm{FN}_{3} \mathrm{~S}$ [M - H] : 298.0820; found: 298.0823 .

$N$-(3-Methoxyphenyl)-5,6,7,8-tetrahydrobenzo[4,5]thieno [2,3-d]pyrimidin-4-amine (3j)

${ }^{1} \mathrm{H}$ NMR $\left(400 \mathrm{MHz}, \mathrm{CDCl}_{3}\right) \delta 8.50(\mathrm{~s}, 1 \mathrm{H}), 7.47-7.42$ (m, 1H), 7.32-7.24 (m, 1H), $7.15(\mathrm{~s}, 1 \mathrm{H}), 7.14-7.10(\mathrm{~m}$, $1 \mathrm{H}), 6.72-6.65(\mathrm{~m}, 1 \mathrm{H}), 3.85(\mathrm{~s}, 3 \mathrm{H}), 3.13-3.02(\mathrm{~m}, 2 \mathrm{H})$, 2.91-2.79 (m, 2H), 2.07-1.87 (m, 4H); ${ }^{13} \mathrm{C} \mathrm{NMR}(100 \mathrm{MHz}$, $\left.\mathrm{CDCl}_{3}\right) \delta 166.29,160.25,154.97,152.55,139.71,134.79$, $129.74,124.73,116.73,113.38,109.27,107.34,55.39$, 26.55, 25.57, 22.59, 22.42; IR (KBr) $v / \mathrm{cm}^{-1} 3443,2925$, 1608, 1565, 1486, 1156, 1043, 779, 679, 521; HRMS (ESI) $\mathrm{m} / \mathrm{z}$, calcd. for $\mathrm{C}_{17} \mathrm{H}_{17} \mathrm{~N}_{3} \mathrm{OS}[\mathrm{M}+\mathrm{H}]^{+}: 312.1165$; found: 312.1161 .

$\mathrm{N}$-(4-Methoxyphenyl)-5,6,7,8-tetrahydrobenzo[4,5]thieno [2,3-d]pyrimidin-4-amine (3k)

${ }^{1} \mathrm{H}$ NMR (400 MHz, $\mathrm{CDCl}_{3}$ ) $\delta 8.44$ (s, 1H), 7.56-7.41 (m, 2H), $7.02(\mathrm{~s}, 1 \mathrm{H}), 6.97-6.87(\mathrm{~m}, 2 \mathrm{H}), 3.83(\mathrm{~s}, 3 \mathrm{H})$, 3.14-2.97 (m, 2H), 2.94-2.77 (m, 2H), 2.06-1.83 (m, 4H); ${ }^{13} \mathrm{C}$ NMR $\left(100 \mathrm{MHz}, \mathrm{CDCl}_{3}\right) \delta 176.04,165.75,156.79$, 155.66, 152.67, 134.42, 131.03, 124.93, 124.21, 116.42, $114.38,55.57,26.57,25.53,22.59,22.45,20.74$; IR (KBr) $\mathrm{V} / \mathrm{cm}^{-1} 3418,2935,1604,1564,1503,1221,1026,829$, 552; HRMS (ESI) $m / z$, calcd. for $\mathrm{C}_{17} \mathrm{H}_{17} \mathrm{~N}_{3} \mathrm{OS}[\mathrm{M}+\mathrm{H}]^{+}$: 312.1165; found: 312.1159 .

1-(3-((5,6,7,8-Tetrahydrobenzo[4,5]thieno[2,3- d] pyrimidin4-yl)amino)phenyl)ethan-1-one (3I)

${ }^{1} \mathrm{H}$ NMR $\left(400 \mathrm{MHz}\right.$, DMSO- $\left.d_{6}\right) \delta 8.40(\mathrm{~s}, 1 \mathrm{H}), 8.32(\mathrm{~s}$, $1 \mathrm{H}), 8.22-8.18(\mathrm{~m}, 1 \mathrm{H}), 8.00-7.95(\mathrm{~m}, 1 \mathrm{H}), 7.71-7.66(\mathrm{~m}$, $1 \mathrm{H}), 7.53-7.46(\mathrm{~m}, 1 \mathrm{H}), 3.18-3.12(\mathrm{~m}, 2 \mathrm{H}), 2.86-2.79(\mathrm{~m}$, 
2H), 2.60 (s, 3H), 1.90-1.83 (m, 4H); ${ }^{13} \mathrm{C}$ NMR $(100 \mathrm{MHz}$, DMSO- $\left.d_{6}\right) \delta 198.18,166.48,155.17,152.44,140.21$, 137.67, 133.65, 129.15, 127.21, 127.10, 123.69, 121.76, $117.45,27.28,25.81,25.56,22.64,22.45 ; \mathrm{IR}(\mathrm{KBr}) \mathrm{v} / \mathrm{cm}^{-1}$ 3443, 2939, 1566, 1508, 1442, 1360, 1262, 964, 775, 680, 534; HRMS (ESI) $\mathrm{m} / 2$, calcd. for $\mathrm{C}_{18} \mathrm{H}_{17} \mathrm{~N}_{3} \mathrm{OS}[\mathrm{M}+\mathrm{H}]^{+}$: 324.1165; found: 324.1162 .

$\mathrm{N}$-(4-Nitrophenyl)-5,6,7,8-tetrahydrobenzo[4,5]thieno [2,3-d]pyrimidin-4-amine (3m)

${ }^{1} \mathrm{H}$ NMR $\left(400 \mathrm{MHz}, \mathrm{CDCl}_{3}\right) \delta 8.60(\mathrm{~s}, 1 \mathrm{H}), 8.36-8.18$ $(\mathrm{m}, 2 \mathrm{H}), 8.03-7.84(\mathrm{~m}, 2 \mathrm{H}), 7.60(\mathrm{~s}, 1 \mathrm{H}), 3.18-3.07(\mathrm{~m}, 2 \mathrm{H})$, 2.96-2.82 (m, 2H), 2.09-1.89 (m, 4H); ${ }^{13} \mathrm{C} \mathrm{NMR} \mathrm{(100} \mathrm{MHz,}$ $\left.\mathrm{CDCl}_{3}\right) \delta 167.17,153.73,152.02,144.82,142.66,136.49$, 125.23, 124.16, 119.33, 117.35, 26.59, 25.64, 22.52, 22.35; IR (KBr) v / cm ${ }^{-1} 3439,2932,2846,1585,1557,1502$, 1435, 1326, 1237, 1181, 1116, 851, 778, 534, 490; HRMS (ESI) $m / z$, calcd. for $\mathrm{C}_{16} \mathrm{H}_{14} \mathrm{~N}_{4} \mathrm{O}_{2} \mathrm{~S}[\mathrm{M}+\mathrm{H}]^{+}: 327.0910$; found: 327.0915 .

$\mathrm{N}$-(3-Ethynylphenyl)-5,6,7,8-tetrahydrobenzo[4,5]thieno [2,3-d]pyrimidin-4-amine (3n)

${ }^{1} \mathrm{H}$ NMR $\left(400 \mathrm{MHz}, \mathrm{CDCl}_{3}\right) \delta 8.50(\mathrm{~s}, 1 \mathrm{H}), 7.80-7.76$ $(\mathrm{m}, 1 \mathrm{H}), 7.76-7.68(\mathrm{~m}, 1 \mathrm{H}), 7.37-7.29(\mathrm{~m}, 1 \mathrm{H}), 7.26-7.22$ (m, 1H), 7.13 (s, 1H), $3.10(\mathrm{~s}, 1 \mathrm{H}), 3.09-3.02(\mathrm{~m}, 2 \mathrm{H})$, 2.91-2.81 (m, 2H), 2.05-1.87 (m, 4H); ${ }^{13} \mathrm{C} \mathrm{NMR}(100 \mathrm{MHz}$, $\left.\mathrm{CDCl}_{3}\right) \delta 166.39,154.66,152.38,138.63,135.04,129.04$, $127.46,124.62,124.20,122.81,121.50,116.71,83.37$, 26.52, 25.56, 22.54, 22.38; IR (KBr) v / cm $\mathrm{cm}^{-1} 3443,3240$, 2939, 1559, 1502, 1438, 1133, 991, 889, 774, 650, 519; HRMS (ESI) $m / z$, calcd. for $\mathrm{C}_{18} \mathrm{H}_{15} \mathrm{~N}_{3} \mathrm{~S}[\mathrm{M}+\mathrm{H}]^{+}: 306.1059$; found: 306.1055 .

\section{$N$-Methyl- $N$-phenyl-5,6,7,8-tetrahydrobenzo[4,5]thieno} [2,3-d]pyrimidin-4-amine (30)

${ }^{1} \mathrm{H}$ NMR (400 MHz, DMSO- $d_{6}$ ) $\delta 8.29(\mathrm{~s}, 1 \mathrm{H}), 7.49-$ $7.37(\mathrm{~m}, 4 \mathrm{H}), 7.29-7.21(\mathrm{~m}, 1 \mathrm{H}), 3.48(\mathrm{~s}, 3 \mathrm{H}), 2.62-2.54$ (m, 2H), 2.50-2.47 (m, 2H), 1.84-1.71 (m, 4H); ${ }^{13} \mathrm{C}$ NMR $\left(100 \mathrm{MHz}, \mathrm{DMSO}-d_{6}\right) \delta 163.24,153.16,143.97,133.15$, $130.00,126.11,125.79,121.11,116.01,98.08,34.80$, $24.65,24.40,23.27,22.21$; IR (KBr) $v / \mathrm{cm}^{-1} 3448,3074$ 2942, 2835, 2208, 1616, 1494, 1352, 1224, 1134, 977, 756, 688; HRMS (ESI) $m / z$, calcd. for $\mathrm{C}_{17} \mathrm{H}_{17} \mathrm{~N}_{3} \mathrm{~S}[\mathrm{M}+\mathrm{H}]^{+}$: 296.1216; found: 296.1222 .

$N$-(3,5-Dimethylphenyl)-5,6,7,8-tetrahydrobenzo[4,5]thieno [2,3-d]pyrimidin-4-amine (3p)

${ }^{1} \mathrm{H}$ NMR $\left(400 \mathrm{MHz}, \mathrm{DMSO}-d_{6}\right) \delta 8.39(\mathrm{~s}, 1 \mathrm{H}), 7.97(\mathrm{~s}$, $1 \mathrm{H}), 7.31(\mathrm{~s}, 2 \mathrm{H}), 6.74(\mathrm{~s}, 1 \mathrm{H}), 3.16-3.10(\mathrm{~m}, 2 \mathrm{H}), 2.87-$ $2.77(\mathrm{~m}, 2 \mathrm{H}), 2.28(\mathrm{~s}, 6 \mathrm{H}), 1.90-1.80(\mathrm{~m}, 4 \mathrm{H}) ;{ }^{13} \mathrm{C} \mathrm{NMR}$ $\left(100 \mathrm{MHz}, \mathrm{DMSO}-d_{6}\right) \delta 166.10,155.38,152.65,139.50$,
$137.92,133.30,127.07,125.37,120.10,117.18,25.84$, 25.54, 22.62, 22.48, 21.55; IR (KBr) v / cm $\mathrm{cm}^{-1} 3451,2942$, 2837, 1614, 1560, 1505, 1450, 1164, 1127, 1042, 820, 519; HRMS (ESI) $m / z$, calcd. for $\mathrm{C}_{18} \mathrm{H}_{19} \mathrm{~N}_{3} \mathrm{~S}[\mathrm{M}+\mathrm{H}]^{+}: 310.1372$; found: 310.1377 .

$N$-(4-(tert-Butyl)phenyl)-5,6,7,8-tetrahydrobenzo[4,5]thieno [2,3-d]pyrimidin-4-amine (3q)

${ }^{1} \mathrm{H}$ NMR $\left(400 \mathrm{MHz}, \mathrm{CDCl}_{3}\right) \delta 8.40(\mathrm{~s}, 1 \mathrm{H}), 7.50-7.43$ $(\mathrm{m}, 2 \mathrm{H}), 7.37-7.31(\mathrm{~m}, 2 \mathrm{H}), 7.06(\mathrm{~s}, 1 \mathrm{H}), 3.03-2.95(\mathrm{~m}$, $2 \mathrm{H}), 2.83-2.74(\mathrm{~m}, 2 \mathrm{H}), 2.00-1.81(\mathrm{~m}, 4 \mathrm{H}), 1.26(\mathrm{~s}, 9 \mathrm{H})$; ${ }^{13} \mathrm{C}$ NMR $\left(100 \mathrm{MHz}, \mathrm{CDCl}_{3}\right) \delta 155.25,152.38,147.38$, 135.49, 134.74, 126.01, 124.87, 121.47, 116.61, 34.45, $31.40,26.53,25.55,22.59,22.42$; IR (KBr) $v / \mathrm{cm}^{-1} 3417$, 2954, 1598, 1560, 1501, 1435, 1316, 1237, 982, 822; HRMS (ESI) $m / z$, calcd. for $\mathrm{C}_{20} \mathrm{H}_{23} \mathrm{~N}_{3} \mathrm{~S}[\mathrm{M}-\mathrm{H}]^{-}: 336.1540$; found: 336.1543 .

$\mathrm{N}$-(3,4-Dichlorophenyl)-5,6,7,8-tetrahydrobenzo[4,5]thieno [2,3-d]pyrimidin-4-amine (3r)

${ }^{1} \mathrm{H}$ NMR $\left(400 \mathrm{MHz}\right.$, DMSO- $\left.d_{6}\right) \delta 8.39(\mathrm{~s}, 1 \mathrm{H}), 8.25(\mathrm{~s}$, $1 \mathrm{H}), 7.97(\mathrm{~d}, J 2.5 \mathrm{~Hz}, 1 \mathrm{H}), 7.63(\mathrm{dd}, J 8.8,2.5 \mathrm{~Hz}, 1 \mathrm{H})$, 7.52 (d, $J 8.8 \mathrm{~Hz}, 1 \mathrm{H}), 3.12-2.98(\mathrm{~m}, 2 \mathrm{H}), 2.83-2.69(\mathrm{~m}$, $2 \mathrm{H}), 1.85-1.71(\mathrm{~m}, 4 \mathrm{H}) ;{ }^{13} \mathrm{C}$ NMR (100 MHz, DMSO- $\left.d_{6}\right)$ $\delta 166.69,154.64,152.34,140.03,134.16,131.05,130.62$, $126.99,124.84,123.29,122.23,117.67,25.72,25.58$, 22.62, 22.40; IR (KBr) v / cm ${ }^{-1} 3447,2936,1596,1554$, 1493, 1434, 1374, 1266, 1128, 990, 805; HRMS (ESI) $m / z$, calcd. for $\mathrm{C}_{16} \mathrm{H}_{13} \mathrm{Cl}_{2} \mathrm{~N}_{3} \mathrm{~S}[\mathrm{M}-\mathrm{H}]=:$ 348.0134; found: 348.0130 .

$\mathrm{N}$-(3,5-Dichlorophenyl)-5,6,7,8-tetrahydrobenzo[4,5]thieno [2,3-d]pyrimidin-4-amine (3s)

${ }^{1} \mathrm{H}$ NMR $\left(400 \mathrm{MHz}\right.$, DMSO- $\left.d_{6}\right) \delta 8.50(\mathrm{~s}, 1 \mathrm{H}), 8.38$ (s, 1H), $7.84(\mathrm{~d}, J 1.9 \mathrm{~Hz}, 2 \mathrm{H}), 7.25(\mathrm{t}, J 1.9 \mathrm{~Hz}, 1 \mathrm{H})$, 3.17-3.07 (m, 2H), 2.91-2.79 (m, 2H), 1.92-1.79 (m, 4H); ${ }^{13} \mathrm{C}$ NMR (100 MHz, DMSO- $\left.d_{6}\right) \delta 166.83,154.45,152.30$, 142.46, 134.39, 134.11, 127.00, 122.27, 119.89, 117.90, 25.69, 25.59, 22.62, 22.39; IR (KBr) v / cm $\mathrm{cm}^{-1} 3444,3103$, 2943, 2845, 1598, 1502, 1446, 1226, 1121, 1000, 837, 811; HRMS (ESI) $m / z$, calcd. for $\mathrm{C}_{16} \mathrm{H}_{13} \mathrm{Cl}_{2} \mathrm{~N}_{3} \mathrm{~S}[\mathrm{M}-\mathrm{H}]^{-}$: 348.0134; found: 348.0138 .

$N$-(3,4-Difluorophenyl)-5,6,7,8-tetrahydrobenzo[4,5]thieno [2,3-d]pyrimidin-4-amine (3t)

${ }^{1} \mathrm{H}$ NMR (400 MHz, DMSO- $\left.d_{6}\right) \delta 8.52(\mathrm{~s}, 1 \mathrm{H}), 8.42$ (s, 1H), 7.56-7.47 (m, 1H), 6.94-6.84 (m, 1H), 3.17-3.08 $(\mathrm{m}, 2 \mathrm{H}), 2.88-2.81(\mathrm{~m}, 2 \mathrm{H}), 1.92-1.83(\mathrm{~m}, 4 \mathrm{H}) ;{ }^{13} \mathrm{C} \mathrm{NMR}$ $\left(100 \mathrm{MHz}, \mathrm{DMSO}-d_{6}\right) \delta 166.86,164.03,163.88,161.62$, $161.47,154.47,152.29,142.57,134.49,126.93,117.94$, 104.51, 104.22, 98.18, 25.63 (d, J 6.4 Hz), 22.62, 22.39; 
IR $(\mathrm{KBr}) \vee / \mathrm{cm}^{-1} 3449,3097,2936,2853,1615,1561$, 1509, 1476, 1441, 1148, 1109, 1030, 989, 827; HRMS (ESI) $m / z$, calcd. for $\mathrm{C}_{16} \mathrm{H}_{13} \mathrm{~F}_{2} \mathrm{~N}_{3} \mathrm{~S}[\mathrm{M}-\mathrm{H}]^{-}: 316.0725$; found: 316.0720 .

$N$-(3,5-Difluorophenyl)-5,6,7,8-tetrahydrobenzo[4,5]thieno [2,3-d]pyrimidin-4-amine (3u)

${ }^{1} \mathrm{H}$ NMR (400 MHz, DMSO- $\left.d_{6}\right) \delta 8.50(\mathrm{~s}, 1 \mathrm{H}), 8.38$ (s, 1H), 7.56-7.46 (m, 2H), 6.87 (tt, $J 9.3,2.3 \mathrm{~Hz}, 1 \mathrm{H})$, $3.12(\mathrm{~m}, 2 \mathrm{H}), 2.84(\mathrm{~m}, 2 \mathrm{H}), 1.85(\mathrm{~m}, 4 \mathrm{H}) ;{ }^{13} \mathrm{C}$ NMR $\left(100 \mathrm{MHz}, \mathrm{DMSO}-d_{6}\right) \delta 166.83,154.45,152.30,142.46$, $134.39,134.11,127.00,122.27,119.89,117.90,25.64$ (d, $J 10.1 \mathrm{~Hz}), 22.62,22.39$; IR $(\mathrm{KBr}) \vee / \mathrm{cm}^{-1} 3449$, 3097, 2937, 2853, 1615, 1561, 1509, 1476, 1441, 1148, $1108,988,826$; HRMS (ESI) $\mathrm{m} / z$, calcd. for $\mathrm{C}_{16} \mathrm{H}_{13} \mathrm{~F}_{2} \mathrm{~N}_{3} \mathrm{~S}$ $[\mathrm{M}-\mathrm{H}]^{-}: 316.0725$; found: 316.0728 .

$\mathrm{N}$-(3-(Trifluoromethyl)phenyl)-5,6,7,8-tetrahydrobenzo [4,5]thieno[2,3-d]pyrimidin-4-amine (3v)

${ }^{1} \mathrm{H}$ NMR (400 MHz, DMSO- $\left.d_{6}\right) \delta 8.37(\mathrm{~s}, 1 \mathrm{H}), 8.33$ $(\mathrm{s}, 1 \mathrm{H}), 8.01(\mathrm{~s}, 1 \mathrm{H}), 7.96-7.88(\mathrm{~m}, 1 \mathrm{H}), 7.56-7.46(\mathrm{~m}$, $1 \mathrm{H})$, 7.38-7.30 (m, $1 \mathrm{H}), 3.13-3.03(\mathrm{~m}, 2 \mathrm{H}), 2.81-2.72(\mathrm{~m}$, $2 \mathrm{H}), 1.83-1.75(\mathrm{~m}, 4 \mathrm{H}) ;{ }^{13} \mathrm{C}$ NMR (100 MHz, DMSO- $\left.d_{6}\right)$ $\delta 166.66,154.90,152.38,140.64,134.01,129.93,129.55$, 127.06, 126.03, 123.35, 119.79 (d, J 3.6 Hz), 118.36 (d, $J$ 4.0 Hz), 117.61, 25.75, 25.58, 22.63, 22.42; IR (KBr) $\mathrm{v} / \mathrm{cm}^{-1} 3445,3095,2947,2870,1567,1510,1442$, 1327, 1164, 1110, 988, 781; HRMS (ESI) $\mathrm{m} / z$, calcd. for $\mathrm{C}_{17} \mathrm{H}_{14} \mathrm{~F}_{3} \mathrm{~N}_{3} \mathrm{~S}[\mathrm{M}-\mathrm{H}]^{-:}$: 348.0788; found: 348.0782 .

$N$-(3-(tert-Butyl)phenyl)-5, 6, 7,8-tetrahydrobenzo $[4,5]$ thieno[2,3-d]pyrimidin-4-amine (3w)

${ }^{1} \mathrm{H}$ NMR (400 MHz, DMSO- $\left.d_{6}\right) \delta 8.35(\mathrm{~s}, 1 \mathrm{H}), 8.08$ (s, $1 \mathrm{H}), 7.63-7.57(\mathrm{~m}, 1 \mathrm{H}), 7.57-7.49(\mathrm{~m}, 1 \mathrm{H}), 7.33-7.22(\mathrm{~m}$, $1 \mathrm{H})$, 7.16-7.05 (m, 1H), 3.19-3.09 (m, 2H), 2.88-2.72 (m, $2 \mathrm{H}), 1.90-1.80$ (m, 4H), 1.30 (s, 9H); ${ }^{13} \mathrm{C}$ NMR $(100 \mathrm{MHz}$, DMSO- $\left.d_{6}\right) \delta 166.19,155.49,152.59,151.55,139.29$, 133.22, 128.40, 127.12, 120.83, 120.25, 119.69, 117.17, $34.92,31.63,25.84,25.55,22.65,22.49$; IR (KBr) $v / \mathrm{cm}^{-1}$ 3453, 3355, 2937, 1603, 1559, 1501, 1438, 1374, 1198, 1131, 992, 784; HRMS (ESI) $\mathrm{m} / \mathrm{z}$, calcd. for $\mathrm{C}_{20} \mathrm{H}_{23} \mathrm{~N}_{3} \mathrm{~S}$ $[\mathrm{M}+\mathrm{H}]^{+}$: 338.1685; found: 338.1696 .

$\mathrm{N}$-(4-(Trifluoromethyl)phenyl)-5,6,7,8-tetrahydrobenzo [4,5]thieno[2,3-d]pyrimidin-4-amine (3x)

${ }^{1} \mathrm{H}$ NMR $\left(400 \mathrm{MHz}, \mathrm{CDCl}_{3}\right) \delta 8.47(\mathrm{~s}, 1 \mathrm{H}), 7.75(\mathrm{~d}$, $J 8.5 \mathrm{~Hz}, 2 \mathrm{H}), 7.55(\mathrm{~d}, J 8.6 \mathrm{~Hz}, 2 \mathrm{H}), 7.22(\mathrm{~s}, 1 \mathrm{H}), 3.02$ (t, $J 6.0 \mathrm{~Hz}, 2 \mathrm{H}), 2.80$ (dd, $J 8.1,3.9 \mathrm{~Hz}, 2 \mathrm{H}), 2.00-1.76$ (m, 4H); ${ }^{13} \mathrm{C}$ NMR $\left(100 \mathrm{MHz}, \mathrm{CDCl}_{3}\right) \delta 166.74,154.37$, $152.25,141.76,135.64,126.31(\mathrm{~d}, J 3.8 \mathrm{~Hz}), 124.4$, $120.21,116.99,26.58,25.60,22.55,22.38$; IR (KBr) $v / \mathrm{cm}^{-1} 3448,2933,2846,1610,1563,1501,1438$, 1324, 1241, 1162, 1107, 1066, 983, 838; HRMS (ESI) $m / z$, calcd. for $\mathrm{C}_{17} \mathrm{H}_{14} \mathrm{~F}_{3} \mathrm{~N}_{3} \mathrm{~S}[\mathrm{M}+\mathrm{H}]^{+}: 350.0933$; found: 350.0912 .

\section{Biological evaluation}

\section{Cytotoxicity assay in vitro}

At first, the cytotoxic activities of target compounds 3a-x were determined against A549, CT26 and HepG2 cell lines in vitro according to MTT assay with Erlotinib as the positive control at $25 \mu \mathrm{M}$. Then, the selected compounds, which have better cytotoxic effects compared to Erlotinib (at $25 \mu \mathrm{M}$ ), were subsequently severally selected to investigate the $\mathrm{IC}_{50}$ values of cytotoxic activity against three tumor cell lines tested at six concentrations $(3.125,6.25,12.5,25,50$ and $100 \mu \mathrm{M})$. MTT was dissolved at $4 \mathrm{mg} \mathrm{mL}^{-1}$ in phosphatebuffered saline (PBS).

The three cancer cell lines were cultured in a Dulbecco's modified Eagle's medium (DMEM) supplemented with $10 \%$ fetal bovine serum (FBS), $100 \mathrm{~g} \mathrm{~mL}^{-1}$ penicillin and $100 \mathrm{~g} \mathrm{~mL}^{-1}$ streptomycin. Cancer cell lines in logarithmic phase were plated at a density of $3 \times 10^{3}$ cells well $^{-1}$ into each well of 96-well microtiter plates with $100 \mu \mathrm{L}$ of DMEM and incubated at $37^{\circ} \mathrm{C}$ for $24 \mathrm{~h}$ in humidified atmosphere containing $5 \% \mathrm{CO}_{2}$. Then, compounds 3a-x solution $(100 \mu \mathrm{L})$ was added into the culture medium and the cancer cells were incubated at same condition $\left(37^{\circ} \mathrm{C}, 5 \% \mathrm{CO}_{2}\right)$ for $72 \mathrm{~h}$. The MTT solution ( $20 \mu \mathrm{L}$ of $4 \mathrm{mg} \mathrm{mL}^{-1}$ MTT in PBS) was added into each well and the cells containing target compounds were further incubated at $37^{\circ} \mathrm{C}$ for $4 \mathrm{~h}$ in $5 \%$ $\mathrm{CO}_{2}$. After removing the culture medium, DMSO $(200 \mu \mathrm{L})$ was then added into each well to dissolve the crystals, shaken mechanically for $10 \mathrm{~min}$, and then optical densities (OD) values at a wavelength of $540 \mathrm{~nm}$ were measured on a microplate reader (SpectraMax 190, Molecular Devices, USA). Survival ratios are expressed in percentages with respect to untreated cells.

\section{Supplementary Information}

Crystallographic data (excluding structure factors) for the structures in this work were deposited in the Cambridge Crystallographic Data Centre as supplementary publication number CCDC 1542488 (3a) and CCDC 1542147 (3c). Copies of the data can be obtained, free of charge, via www.ccdc.cam.ac.uk/conts/rtrieving.html or from the Cambridge Crystallographic Data Centre, CCDC, 12 Union Road, Cambridge CB2 1EZ, UK; fax: +44 1223336033. E-mail: deposit@ccdc.cam.ac.uk. 
Supplementary data associated with this paper can be found, in the online version, at http://jbcs.sbq.org.br as PDF file.

\section{Acknowledgments}

The authors greatly acknowledge financial support of this research by the Jiangsu Prospective Joint Research Project (No. BY2016066-02) and College Students Innovation Project (No. 201410324014Z).

\section{References}

1. Chen, W.-L.; Carlo, C. D.; Devery, D.; McGrath, D. J.; McHugh, P. E.; Kleinsteinberg, K.; Jockenhoevel, S.; Hennink, W. E.; Kok, R. J.; Int. J. Pharm. 2018, 548, 803.

2. Brocklesby, K. L.; Waby, J. S.; Cawthorne, C.; Smith, G.; Tetrahedron Lett. 2017, 58, 1467.

3. Athar, M.; Ranjan, P.; Jha, P. C.; J. Mol. Graphics Modell. 2018, 84,160 .

4. Yamamoto, Y.; Saita, T.; Yamamoto, Y.; Shin, M.; J. Pharm. Anal. 2018, 8, 119.

5. Batchelor, T. T.; Gerstner, E. R.; Ye, X.-B.; Desideri, S.; Duda, D. G.; Peereboom, D.; Lesser, G. J.; Chowdhary, S.; Wen, P. Y.; Grossman, S.; Supko, J. G.; Neuro-Oncology 2016, 19, 567.

6. Cheng, X.-W.; Lv, X.; Qu, H.-Y.; Li, D.-D.; Hu, M.-M.; Guo, W.-Z.; Ge, G.-B.; Dong, R.-H.; Acta Pharm. Sin. B 2017, 7, 657.

7. Habib, N. S.; Soliman, R.; El-Tombary, A. A.; EI-Hawash, S. A.; Shaaban, O. G.; Med. Chem. Res. 2013, 22, 3289.

8. Zaher, N. H.; Salem, A. A. M.; Ismail, A. F. M.; J. Photochem Photobiol., B 2016, 165, 328.

9. Wang, T.; Zheng, C.-H.; Liu, S.; Chen, H.-Z.; Phosphorus, Sulfur Silicon Relat. Elem. 2010, 185, 1543.

10. Song, X.-J.; Yang, P.; Gao, H.; Wang, Y.; Dong, X.-G.; Tan, X.-H.; Chin. Chem. Lett. 2014, 25, 1006.

11. Jeon, M. K.; Kim, J. G.; Lee, D. H.; Bull. Korean Chem. Soc. 2016, 37, 1406.

12. El-Sayed, N. N. E.; Abdelaziz, M. A.; Wardakhan, W. W.; Mohareb, R. M.; Steroids 2016, 107, 98.

13. Yang, J. S.; Park, C. H.; Lee, C.; Kim, H.; Oh, C.; Choi, Y.; Kang, J. S.; Yun, J.; Jeong, J. H.; Kim, M. H.; Han, G.; Eur. J. Med. Chem. 2014, 85, 399.

14. Kandeel, M. M.; Refaat, H. M.; Kassab, A. E.; Shahin, I. G.; Abdelghany, T. M.; Eur. J. Med. Chem. 2015, 90, 620.

15. Rashad, A. E.; Ali, M. A.; Nucleosides, Nucleotides Nucleic Acids 2006, 25, 17.

16. Baran, A. U.; Tel, B. C.; Sarıgöl, D.; Öztürk, E. I.; Kazkayasi, I.; Okay, G.; Ertan, M.; Tozkoparan, B.; Eur. J. Med. Chem. 2012, 57, 398.

17. Deng, J.; Peng, L.; Zhang, G.-C.; Lan, X.-B.; Li, C.-F.; Chen, F.-X.; Zhou, Y. Y.; Lin, Z. X.; Chen, L.; Dai, R.-K.; Xu, H. J.;
Yang, L.; Zhang, X.-Q.; Hu, W.-H.; Eur. J. Med. Chem. 2011, $46,71$.

18. Yang, C.-R.; Peng, B.; Cao, S.-L.; Ren, T.-T.; Wei, J.; Wang, F.-C.; Li, Y.-S.; Wang, G.; Zheng, L.; Xu, S.-B.; Liao, J.; Wang, H.-L.; Li, J.; Xu, X.-Z.; Eur. J. Med. Chem. 2018, 154, 324.

19. Gryshchenko, A. A.; Bdzhola, V. G.; Balanda, A. O.; Briukhovetska, N. V.; Kotey, I. M.; Golub, A. G.; Ruban, T. P.; Lukash, L. L.; Yarmoluk, S. M.; Bioorg. Med. Chem. 2015, 23, 2287.

20. Abbas, S. E.; Abdel Gawad, N. M.; George, R. F.; Akar, Y. A.; Eur. J. Med. Chem. 2013, 65, 195.

21. Park, C. H.; Lee, C.; Yang, J. S.; Joe, B. Y.; Chun, K.; Kim, H.; Kim, H. Y.; Kang, J. S.; Lee, J. I.; Kim, M. H.; Han, G.; Bioorg. Med. Chem. Lett. 2014, 24, 2655.

22. Bowers, S.; Truong, A. P.; Neitz, R. J.; Neitz, R. J.; Hom, R. K.; Sealy, J. M.; Probst, G. D.; Quincy, D.; Peterson, B.; Chan, W.; Galemmo Jr., R. A.; Konradi, A. W.; Sham, H. L.; Tóth, G.; Pan, H.; Lin, M.; Yao, N.; Artis, D. R.; Zhang, H.; Chen, L.; Dryer, M.; Samant, B.; Zmolek, W.; Wong, K.; Lorentzen, C.; Goldbach, E.; Tonn, G.; Quinn, K. P.; Sauer, J. M.; Wright, S.; Powell, K.; Ruslim, L.; Ren, Z.; Bard, F.; Yednock, T. A.; Griswold-Prenner, I.; Med. Chem. Lett. 2011, 21, 5521.

23. Phoujdar, M. S.; Kathiravan, M. K.; Bariwal, J. B.; Shah, A. K.; Jain, K. S.; Tetrahedron Lett. 2008, 49, 1269.

24. Prasad, M. R.; Kishore, D. P.; Chem. Pharm. Bull. 2007, 55, 776.

25. Kassab, A. E.; Gedawy, E. M.; Eur. J. Med. Chem. 2013, 63, 224.

26. Bassetto, M.; Leyssen, P.; Neyts, J.; Yerukhimovich, M. M.; Frick, D. N.; Brancale, A.; Eur. J. Med. Chem. 2016, 123, 31.

27. Pédeboscq, S.; Gravier, D.; Casadebaig, F.; Hou, G.; Gissot, A.; Giorgi, F. D.; Ichas, F.; Cambar, J.; Pometan, J. P.; Eur. J. Med. Chem. 2010, 45, 2473.

28. Tan, Q.; Zhang, Z.-T.; Hui, J.; Zhao, Y.; Zhu, L.; Bioorg. Med. Chem. 2014, 22, 358.

29. Jain, K. S.; Kathiravan, M. K.; Bariwal, J. B.; Chaskar, P. K.; Tompe, S. S.; Arya, N.; Synth. Commun. 2013, 43, 719.

30. Cheng, X.-M.; Liu, X.-W.; J. Comb. Chem. 2007, 9, 906.

31. Sun, Y.-Q.; Zong, C.-Y.; Ji, J.-Y.; Han, Q.; Chem. Pap. 2018, $72,2965$.

32. Zong, C.-Y.; Gu, H.-W.; Zhang, L.-J.; Jin, Y.-D.; Sun, Y.-Q.; Chin. J. Org. Chem. 2018, 38, 1165.

33. Zong, C.-Y.; Zhang, L.-J.; Gu, M.-T.; Sun, Y.-Q.; Chin. J. Org. Chem. 2018, 38, 1422.

34. Wu, C.-H.; Coumar, M. S.; Chu, C.-Y.; Lin, W.-H.; Chen, Y.-R.; Chen, C.-T.; Shiao, H.-Y.; Rafi, S.; Wang, S.-Y.; Hsu, H.; Chen, C.-H.; Chang, C.-Y.; Chang, T.-Y.; Lien, T.-W.; Fang, M.-Y.; Yeh, K.-C.; Chen, C.-P.; Yeh, T.-K.; Hsieh, S.-H.; Hsu, J. T.-A.; Liao, C.-C.; Chao, Y.-S.; Hsieh, H.-P.; J. Med. Chem. 2010, 53, 7316. 
35. Wang, F.-S.; Gao, H.; Yang, P.; Wang, Y.; Song, X.-J.; Lett. Org. Chem. 2014, 11, 700 .

36. Sridhar, M.; Rao, R. M.; Baba, N. H. K.; Kumbhare, R. M.; Tetrahedron Lett. 2007, 48, 3171.

37. Tayebee, R.; Javadi, F.; Argi, G.; J. Mol. Catal. A: Chem. 2013, 368, 16.

38. Wang, D.-F.; Gao, H.; Tan, X.-H.; Li, W.-M.; Wang, J.; Wu, Y.-J.; Song, X.-J.; Adv. Mater. Res. 2014, 887, 661.

39. Zhao, D.-D.; Li, L.; Xu, F.; Wu, Q.; Lin, X.-F.; J. Mol. Catal. B: Enzym. 2013, 95, 29.
40. Abaee, M. S.; Cheraghi, S.; J. Sulfur Chem. 2014, 35, 261.

41. Loidreau, Y.; Dubouilh-Benard, C.; Marchand, P.; Nourrisson, M. R.; Duflos, M.; Buquet, C.; Corbière, C.; Besson, T.; J. Heterocycl. Chem. 2013, 50, 1187.

42. Peter, B.; Gyorgy, K.; Laszlo, O.; Zsolt, S.; Frigyes, W.; WO pat. 2009104026 A1 2009.

43. Issa, S. A. A.; Orient. J. Chem. 2014, 30, 469.

44. Sheldrick, G. M.; Acta. Cryst. 2008, A64, 112.

Submitted: October 17, 2018 Published online: March 19, 2019 